Bu makaleye atıfta bulunmak için/To cite this article:

SAĞLAM, T. (2021). Bir Caddenin Olușum Evreleri: Erzurum Cumhuriyet Caddesi. Atatürk Üniversitesi Sosyal

Bilimler Enstitüsü Dergisi, 25 (3), 1171-1199.

\title{
Bir Caddenin Oluşum Evreleri: Erzurum Cumhuriyet Caddesi
}

\author{
Temel $S A \breve{G} L A M^{(*)}$
}

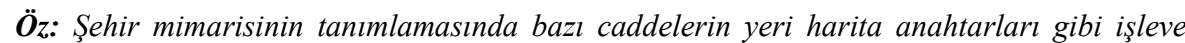
sahiptir. Erzurum şehir yapılanmasında da "Cumhuriyet Caddesi", şehrin kurulduğu miladi 415 yllından beri bu tür bir görev üstlenmiştir. Doğu Roma döneminde oval hatlara sahip olan cadde, Saltukoğulları hâkimiyetinde, Tebrizkapısı ile Caferiye Camii arasında, kent meydanı biçiminde kullanılmış ve her iki yakasına yapı sanatının şahideleri dikilmiştir. İlhanlıların caddeyi Erzincankapı-Mumcu istikametine kadar uzattıklarını, günümüze kadar gelen yapı sanatı örneklerinden anlamaktayız. Kanuni Sultan Süleyman'ın 1535 yllındaki planl ilk imar sırasında, şehri koruyan ilk sur duvarı hem doğu hem de batı cihetinde sur kapılarını aşarak büyümüştür. Osmanlı Devleti eliyle yapılan planlı yapılaşma, şehrin diğer bütün sokaklarını, bu caddeye bağlamış ve Lalapaşa Camii güneyindeki Beylerbeyi Sarayı merkezine taşımıştır. Osmanl döneminde Cumhuriyet Caddesi’nin biçimi, gelişen teknoloji ve tercih değişiklikleri nedeniyle çok kere yenilenmiştir. Genç Cumhuriyet hâkimiyetinde cadde, 1938 Lambert planı ile Çaykara Deresi'ni batıya geçerek ă̆ırlık merkezini "Havuzbaşı" kavşağına yöneltmiştir. Günümüze gelinceye kadar bazı değişikliklerle yinelenen Cumhuriyet Caddesi, Erzurum şehrinin mimari yapılaşma özetini sunmaktadır.

Anahtar Kelimeler: Geleneksel mimari, ulusal mimari, Erzurum, sokak dokusu, Cumhuriyet Caddesi.

\section{The Formation of a Street: Erzurum Cumhuriyet Avenue}

Abstract: The location of some streets in the definition of urban architecture has a function like map legends. In the Erzurum city structuring, "Cumhuriyet Caddesi" has undertaken such a task since the year 415 when the city was founded. The street, which had oval lines in the Eastern Roman period, was used as a city square between Tabrizkapisi and Caferiye Mosque under the rule of Saltukoğullart, and witnesses of building art were erected on both sides. We understand that the Ilkhanians extend the street to the Erzincankapl-Mumcu direction from the examples of building art that have survived until today. During the first planned reconstruction of Suleiman the Magnificent in 1535, the first fortification wall that protected the city grew beyond the fortification gates in both the east and west sides. The planned construction made by the Ottoman State connected all the other streets of the city to this street and moved it to the center of Beylerbeyi Palace to the south of Lalapaşa Mosque. During the Ottoman period, the physics of Cumhuriyet Street were renewed many times due to the developing technology and changes in preference. Under the rule of the Young Republic, the street crossed Çaykara Creek to the west with the 1938 Lambert plan and directed its center of gravity to the "Havuzbaşl" intersection. Cumhuriyet Caddesi, which has been repeated with some changes until today, offers the summary of the architectural construction of the city of Erzurum.

\footnotetext{
* Dr., Milli Eğitim Bakanlığı Erzurum Şükrüpaşa İlkokulu (e-posta: saglamtemel04@gmail.com) (D) ORCID ID.https://orcid.org/0000-0002-4633-5688

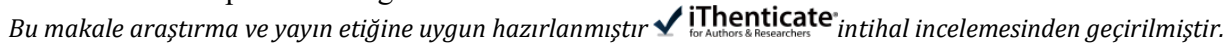


Keywords: Traditional architecture, national architecture, Erzurum, street texture, Cumhuriyet Street.

Makale Gelis Tarihi: 25.05.2021

Makale Kabul Tarihi: 20.09.2021

DOI: 10.53487/ataunisosbil.942929

\section{GİRIS}

Erzurum şehir yapılanması ile eş zamanlı olarak imar gören Cumhuriyet Caddesi, şehre hâkim olan bütün medeniyetlerin kültür katmanını üzerinde barındıran çok geniş veriler taşımaktadır. Caddede izlerini takip ettiğimiz bu katmanlar; şehrin tarihini, ticari yapısını, yönetim biçimini, dini eğilimlerini, eğitim yöntemlerini, imar ve iskânını, mimari dokusunu, sosyal ve içtimai yapısını ele veren unsurlar barındırmaktadır. Cumhuriyet Caddesi'nin oluşum sürecini takip ederek, şehrin hem fiziki yapısının hem de kimliğinin tespiti ile ilgili geniş bir malumata ulaşılmış olunacaktır. Ritmik düzen de denilen organik oluşumla başlayan şehirleşme yapısının metrik sistem olan geometrik düzene dönüşümü sürecinde geçirdiği evrimin görüngüsü, cadde tanımlaması ile netleşecektir.

Erzurum şehir halkının tarihi süreç içerisinde karakteristik özelliklerini yansıtan "mekânsal mantığı", Cumhuriyet Caddesi gibi beşerî oluşumlarda aranmalıdır. Doğu Roma İmparatorluğu döneminde askeri garnizon yerleşim kültürünü (Konukçu, 1989: 4) yalnızca sur ve iç kale yapılanmaları değil, caddenin her iki yanına dizili olan birbirine yaslı ve simetrik hilani ev (Sağlam ve Yurttaş, 2020: 423) diziliminde de görebilmekteyiz. Saltukoğullarının caddeye; ticaret, ibadet ve eğitim alanlarına yönelik mimarinin yanı başına mezar yapılarını da eklemesi (Özkan, 2002: 72-82), nefes alan yaşam kültürünün mekân mantığıdır. Selçuklu hâkimiyeti sırasında tarihi "İpek Yolu" güzergâhı nedeni ile iktisadi durumu gelişen şehrin nüfusu artmış ve buna bağlı olarak Cumhuriyet Caddesi de kıymetlenmiştir (Pamuk, 2007: 127). İlhanlı dönemi kültürünün, yukarı illerin yaşam felsefesi olan, insanı ihya etme mertebesine geldiği; caddenin farklı cihetlerine yapılan medrese ve kütüphanelerden anlaşılmaktadır (Yurttaş ve Köşklü, 2017).

Osmanlı Devleti eliyle kurumsal bir kent hüviyetine kavuşan şehir, caddenin her iki yanına yapılan idari ve sosyal yapılarla şenlendirilmiştir. Mevcut yapılaşmanın yanına eklenen ticari, siyasi ve ilmi yapılar ile birlikte konut mimarisinin de bu dönemde evrildiği anlaşılmaktadır. Osmanlı İmparatorluğu'nun son döneminde başlayan Türk Modernleşmesi de şehrin en bilinen yeri Cumhuriyet Caddesi'nde öncelikle izlenebilmektedir (Kulözü, 2016: 24).

Erzurum şehri üzerinde hâkimiyet kurmuş olan medeniyetlerin dokusu dişında Cumhuriyet Caddesi'ni biçimlendiren ve bağımsız olarak ele alınması gereken bir diğer etken de tarihi İpek Yolu ticaretidir. Batı dünyasına gerekli olan ipeğin Orta Asya bozkır ve yüksek dağlarından geçerek taşındığı bu yol, yalnızca bir güzergâh üzerinden değil zamanla farklı kollarla bütünleşen çok büyük bir ticari ulaşım ağına dönüşmüştür. Erzurum şehri, kuruluşundan itibaren Doğu Roma'nın güvenli sınır kale şehri 
olmasının yanında İpek Yolu'nun Kuzey Anadolu kolunun önemli bir durağı olmuştur (Pamuk, 2007: 126). İpek Yolu ticari etkinlikleri arttıkça şehrin nüfusu ve ekonomisi büyümüş, cadde üzerinde yapılan mimari yapılaşma da zenginleşmiştir.

Erzurum şehrinin kuruluşuna sebep olan iç kalenin hemen ardından kent makroformunu etkileyen en eski ve en önemli oylum Cumhuriyet Caddesi'dir. Bu caddenin gelişim evreleri, şehrin dönemsel döngülerini de barındırmaktadır. $\mathrm{Bu}$ nedenledir ki Cumhuriyet Caddesi'ni bilmek, Erzurum'u bilmekle eş değer sayılmalidir.

\section{ERZURUM CUMHURIYYT CADDESI'NIIN OLUŞUM EVRELERİ}

Erzurum Cumhuriyet Caddesi'nin gelişimi, şehrin kuruluşu ile başlamaktadır. Erzurum'a hâkim olan medeniyetlerin kültür katmanları ile gelişen, değişen ve büyüyen cadde, günümüzde de şehrin en yoğun alanını oluşturmaktadır.

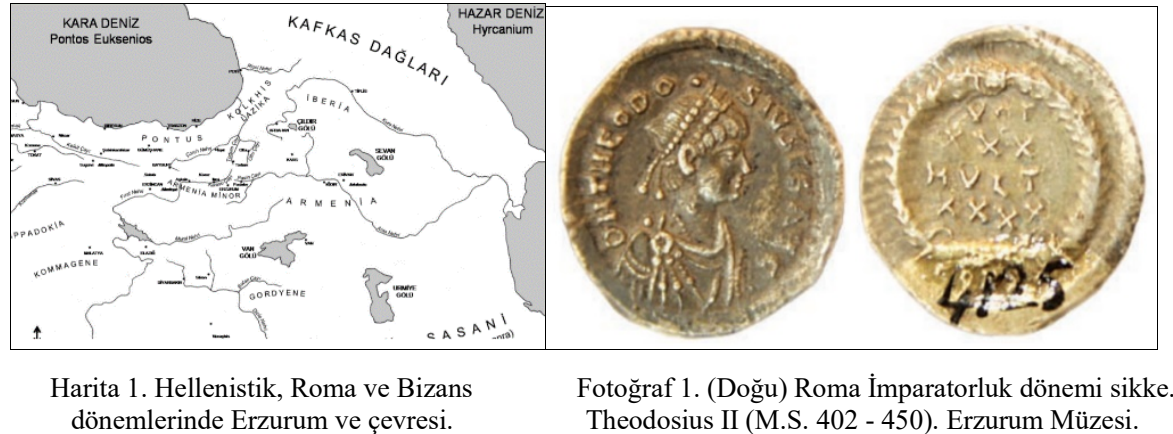

A. Erzurum Şehrinin Kuruluşundan Osmanlı Dönemine Kadar, Erzurum Cumhuriyet Caddesi

Cumhuriyet Caddesi'nin ilk olarak kuruluşu, Erzurum şehrinin günümüzdeki yerleşim yerine ilk imarı ile başlamaktadır. Şehrin günümüzdeki kurulum yeri, sekizinci yüzyıla tarihlenen eski bir yazma kitapta, Doğu Roma İmparatoru II. Theodosius dönemi (408-450) siyasi olaylarının anlatıldığı bölümde; İmparatorun Erzurum'da bir kale yaptırarak burasını müstahkem bir kale şehri oluşturmak istediğinden bahsedilmektedir. Karin' de ${ }^{1}$ oturan Büyük Patrik'in ${ }^{2}$ kendisine yazdığ 1 bir mektup üzerine bu kararı aldığı belirtilmektedir. İmparator, generallerinden Anatolius'u Karin'de kale kurulacak alanı belirlemek için bölgeye göndermiştir. Anatolius, kale yapımına uygun bir yer bulmak için günlerce dolaşıp araştırma yaptıktan sonra muhtelif küçük derelerin peyda olduğu bir dağın eteğindeki günümüz kalesinin yerini tespit ettiği anlatılmaktadır. General Anatolius bu alanı imparatora;

\footnotetext{
${ }^{1}$ Erzurum'un eski adlarından birisi.

${ }^{2}$ Tebrizkapı civarında olduğu düşünülen Kara Manastır Kilisesi patriği.
} 
"Küçük dereler, birleşerek vücuda getirdikleri bir denize akmaktadirlar" diye tarif etmektedir (Horenli Moses, 2006: 331; Tozlu, 2011: 1). Anlatıya göre Büyük Roma İmparatorluğu döneminde, Karin/Karinitis adıyla bilinen ve küçük bir yerleşim olan Erzurum, Doğu Roma İmparatorluğu (Bizans) zamanında İmparator II. Theodosius (MS. 402-450) tarafindan 415'li yıllarda kurulmuștur (Can, 2010: 37). Bir garnizon şehri olarak kurulduğunu bildiğimiz Erzurum yerleşkesinin etrafı da surlarla çevrilmiş̧ir (Küçükuğurlu, 2018a: 18).

Bizans İmparatorluğu döneminde (395-1071) ${ }^{3}$ Bizans'nn hâkimiyetindeki diğer şehirlerde olduğu gibi yuvarlağa yakın bir surun çevirdiği alan, meydan şeklinde tasarlanmıştır. Bu meydanın etrafına yerleştirilen şehrin, farklı yapı elamanları ile birlikte, caddesi de planlı olarak eklenmiştir. 415 yılında kurulan şehrin doğu yönünde Tebrizkapı istikametindeki "Agusteum" (Adontz, 1970: 119-120) sur kapısından batıda Bölge İdare Mahkemesi kısmında yer alan "Anastasius" (Manandian, 1965) kule kapısı arasında "Petomata Viam" adını verdikleri kale yolu, Cumhuriyet Caddesi'nin ilk adı ve imarıdır. Bu dönemde caddeyi, kuzey taraftan sazlığa, güney taraftan da "Keçi Memeleri” diye adlandırılan Palandöken Dă̆ı'na bağlayan tünellerin varllğı̆ndan da söz edilmektedir (Horenli Moses, 2006: 331-332). Dağdan getirilen su kanalları bu meydan caddenin muhtelif yerlerinden akıtılmaktaydı. Su yaklaşık altmış santim yüksekliğindeki künklerden lülesiz olarak taş arklara akmaktaydı. Erzurum çeşmelerinin (Yurttaş ve Özkan, 2002) ilk uygulama örneğini oluşturulan bu su kanallarının suyunun çok temiz olduğu da kaydedilmiştir (Küçükuğurlu ve Çelik, 2013: 84-85).

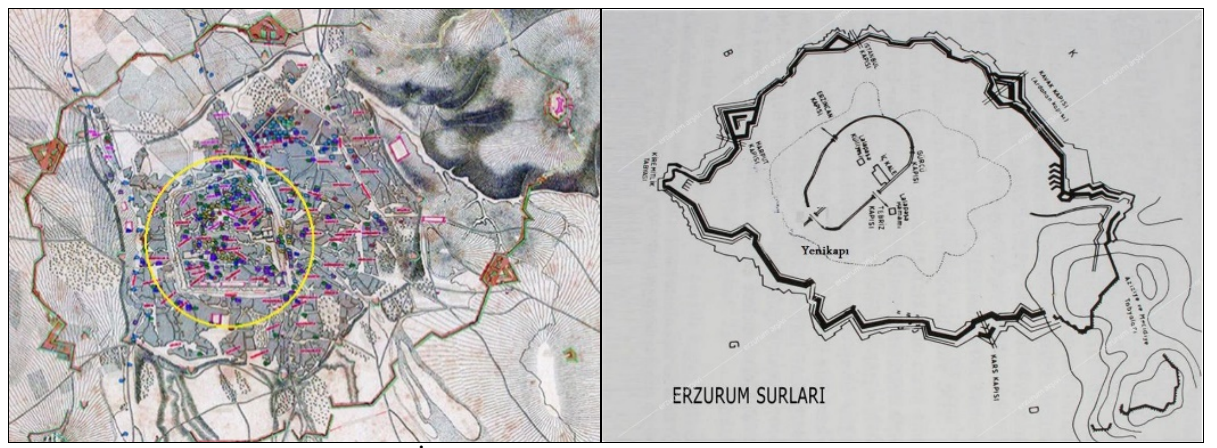

Harita 2. Bizans döneminde Erzurum İç Kale ve ilk surları; 1877-78 Osmanl1-Rus Savaşı Erzurum Askeri Sur Haritası (Erzurum Arşivi).

\footnotetext{
${ }^{3}$ Bizans İmparatoru II. Theodosius döneminde (MS 408-450) 415 yılında şehir, ilk surlarıyla birlikte kurulmuştur. İmparator I. Anastasius zamanında (MS 491-518) kalenin bulunduğu tepeyi çepeçevre çeviren surlar yaptırılmış, kale kapıları eklenmiş̧ir. Bu dönemde caddenin uzatıldığ 1 taş döşemelerinin yenilenerek su kanallarının eklendiği düşünülmektedir. İmparator I. Justinianus döneminde (MS 527-568) şehrin surları yeniden tahkim ettirilmiş, cedde de onarılmıştır. Bu dönemde şehir; hisar, şehir ve varoşlar olmak üzere üç bölümden oluşmaktaydı. Herakleios zamanında (MS 610-641) yeniden imar ve iskân gören şehrin "Thema Sistemi" ile kurumsal yapılara kavuştuğu bilinmektedir.
} 
Caddenin ilk büyük değişikliği, İmparator Herakleios devrinde (MS 610-641) şehrin idaresinin bilinen eyalet yönetim biçimine çevrildiği "Thema Sistemi" ile kazandığı kamusal yapı eklemeleri ile olmuştur. Bu dönemde meydan şeklindeki caddenin her iki yanına yapılan kamu idare binaları ve askeri kıt'alar (Kürkçüoğlu, 2007: 47) nedeniyle cadde, sokak biçimi almaya başlamıştır. Bu tarihten sonra Bizans ve İslam orduları arasında sürekli el değiştiren şehre Emevi ve Abbasilerin mimari yapılarla eklemeler yaptıkları, "Kali nisbetini" taşıyan çok sayıdaki âlim ve şair isminden anlaşılmaktadır (Kürkçüoğlu, 2007: 51). Günümüzde Yakutiye Belediyesi binasının arka tarafında bulunan Kâbe Mescidi, giriş kapısı üzerindeki taş kitabesindeki, "El Mescidü'l Kâbe, sene 29" yazısından hareketle 651 yılında Emeviler döneminde yapılmıştır (Küçükuğurlu, 2020: 41). 300 yıla yakın Müslümanların idaresinde kalan şehrin yapısal değişikliğinin hisar ve şehirde çok değil, varoş ${ }^{4}$ bölümlerde, özellikle de dini mimari alanda, olduğu belirlenebilmektedir. Bu nedenle Müslüman idaresinde "Tarık-1 Kala" denilen cadde üzerinde önemli bir mimari değişimin olmadığı izlenebilmektedir. Erzurum VII. Konstantinos zamanında (908959) 949 yılında Bizans İmparatorluğu'na bağlanmış, yeniden imar edilmiş ve Türkİslam hâkimiyetine kadar Bizans şehri olarak kalmıştır. Son dönemde yapılan imar etkinlikleri, yeni yapılanma yerine, tadilat ve onarım şeklinde olmuştur.

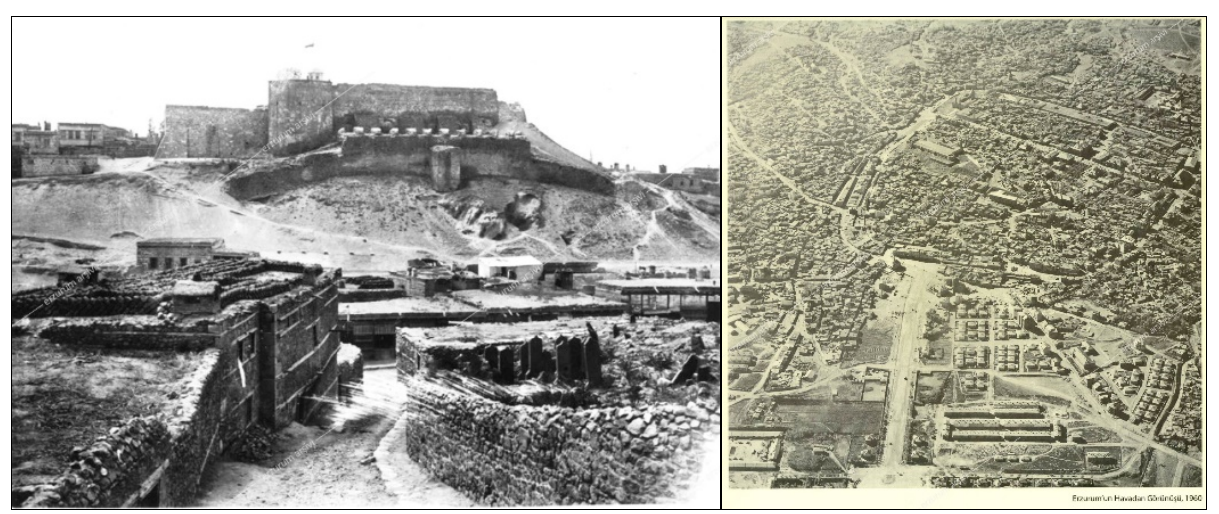

Fotoğraf 2. Bizans döneminde yapılan İç Kale ve hava fotoğrafinda orta kısımda görülen ilk sur adası, 20. yy. ortaları (Erzurum Arşivi).

Erzurum şehri ve ilk caddesi, ikinci büyük imarını Saltukoğulları döneminde görmüştür. Malazgirt Zaferi sonrasında 1080 yılında kurulan Saltukoğulları Beyliği zamanında (1080-1202) cadde, iç meydanla birlikte kimlik değiştiren mimari unsurlardan biri olmuştur. İslami yönetim dönemlerinde iç meydan ve caddeden ziyade

\footnotetext{
${ }^{4}$ Ortaçağdaki kale şehirler, üç bölümden oluşmaktadır. Hisar, şehir ve varoşlar olmak üzere idari yapılanma gösteren şehrin en önemli kısmı, iç meydanın da içinde kaldığı surla çevrili olan iç kale alanıdır.
} 
şehir ve varoşlarda yapılan imar uygulamaları, Saltuklular zamanında hisar kısmında yoğunlaşmıştır (Kürkçüoğlu, 2007: 79). Bu dönemde hisar bölümünü çevreleyen sur duvarları korunmuş ve onarımlarla daha muhkem hale getirilmiştir. Bizans sarayının bulunduğunu tahmin ettiğimiz Esatpaşa sırtlarında Saltuklu sarayının yapılmış olma ihtimali de vardır. 1124-1132 yıllarında Saltuklu hükümdarı Ziyaeddin Gazi tarafından yaptırılan Tepsi Minare bu dönemin mimari yapılanmasının ne denli büyük olduğunu göstermesi açısından ilk örnektir. Saltuklu hükümdarı Nasıreddin Muhammed'in (1168-1191) 1179 yılında yaptırdığ “Atabek/Ulu Camii" (Yurttaş, 2001: 191) "Rah-1 hisar" dedikleri caddenin en belirgin biçimlendiricilerinden biri olmuştur. Ulu Cami, yalnızca caddenin güney sınır çizgisini belirlememiş aynı zamanda da kent meydanının (Arslan, 2020) merkezi çekim noktası olmuştur. Caddenin yaklaşık olarak dört yüz yıl sürecek olan bu merkezi kent meydanı karakteri, mimarinin Türk-İslam hüviyetine evrilmesine de şahit olmuştur.

İslam mimarisinin tasarım aşamasında, toplanmayı, bütün olmayı, birlenmeyi yani tevhidi işaret eden merkez sembolizmi, Kâbe'den başlayarak şehirlerin kuruluşu ve bağımsız yapıların tasarımına kadar, Müslüman mimarlığın asli kaidelerinden sayılmıştır (Arpacioğlu, 2006: 38). Kâbe merkez sembolizmi, yalnızca büyük kozmosun dönme hareketini, kendi etrafında tavaf eden Müslümanlar tarafından değil, dünya coğrafyasının bütün mabetlerindeki namaza kıyam eden Müslüman saf düzeninin yönelim birliğini de ifade etmektedir. İslam şehri, özellikle cami mimarisine yüklenen bu merkez tasarım anlatısı ile Erzurum'da olduğu gibi inşa edilen Ulu Cami etrafında gelişmiştir (Sağlam, 2020: 259-260). Bu nedenle İslam şehirlerinde olduğu gibi, Erzurum şehir imarında da en dar sokaklardan en geniş Rah-1 hisara kadar her yönelim Ulu Cami merkezine doğru tasarlanmıștır. Saltuklular bir yandan İslami mimari amilleri ile imar ettikleri Erzurum şehrini, bir yandan da Türklük vasfını taşıyan imgelemler ile donatmışlardır. Bu, yalnızca Orta Asya Türk çadırı biçiminde yapılan ve aynı zamanda "ata kültüne" öykünen "Üç Kümbetler" anıt mezar mimarisi gibi büyük boyutlu yapılarla değil aynı zamanda taşlara işlenen usta monogramları (Günaşdı, 2015: 232) ile de tespit edilmiştir. Saltuklular döneminde cadde, her ne kadar kent meydanı biçiminde şekillenmiş olsa da eklenen ticari ve kamu yapılarıyla yeni bir işlev kazanmıştır. İpek Yolu transit ticaretinin geliştiği bu yıllarda (Bozkurt, 2000: 372) cadde bir yandan yüklü ulaşım yükünü taşırken diğer yandan ticari meydan olarak da canlı bir pazar konumuna dönüştürülmüştür.

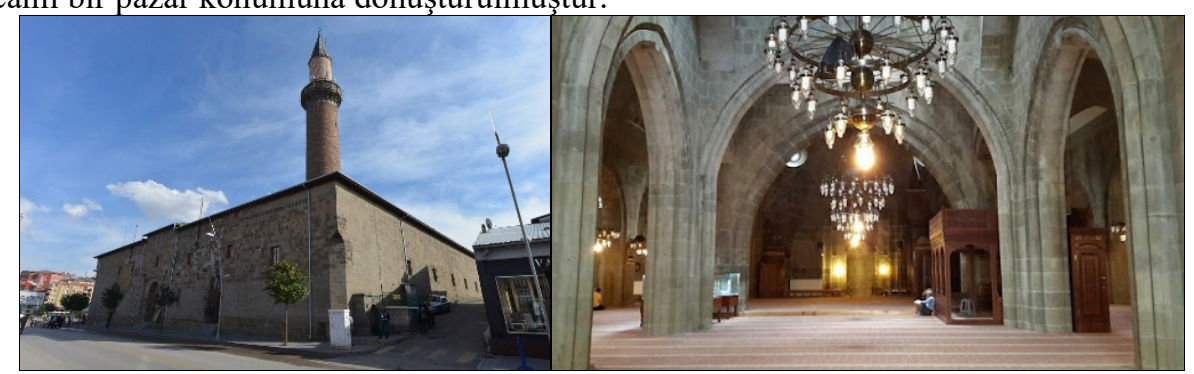

Fotoğraf 3. Erzurum Ulu/Atabek Camii 
Erzurum Selçukluları (1202-1230) ve Anadolu Selçuklu hâkimiyeti (1230-1242) dönemlerinden kalma mimari anıt örneği günümüze ulaşamamış olsa da bu dönemde şehir, çok zengin ve gelişmiş ticaret merkezi haline gelmiştir (Gürbüz, 2004: 119). 1226 yılında Erzurum şehir meydanından tek seferde 20.000 koyunun Tebriz'e sevk edilme anlatısı (İbn Esir, 1985: 462), ekonomik büyüklüğü ve ticaretin hacmini göstermesi açısından oldukça dikkat çekicidir. Erzurum Selçuklu Beyliği’nin Anadolu Selçuklu topraklarına ilhakından sonra şehirdeki ticari büyüklük ve refah seviyesi daha da yükselmiş ve buna bağlı olarak nitelikli göç almıştır. 1236 yılında Erzurum’u görüp buraya yerleşen Kazvinli Tüccar Emir Şemseddîn, şehrin ticari mal ve imkânlar bakımından bir cennet olduğundan bahsetmektedir (İbn Bîbî, 1996: 448). Sadece bu alıntı bile şehrin Selçuklu zamanında çok gelişmiş ticaret merkezi konumunu ortaya koymaktadır. Bu dönemde de Saltukoğulları hâkimiyetinde olduğu gibi, Tarık-1 Kala ya da Rah-1 Hisar olarak adlandırılan caddenin iç meydan biçiminde canlı bir ticaret merkezi olduğu anlaşılmaktadır. Selçuklular zamanında, Bizans döneminde yapılan "Anastasius" kule kapısının aşılarak caddenin batıya doğru genişlediği düşünülmektedir ${ }^{5}$.

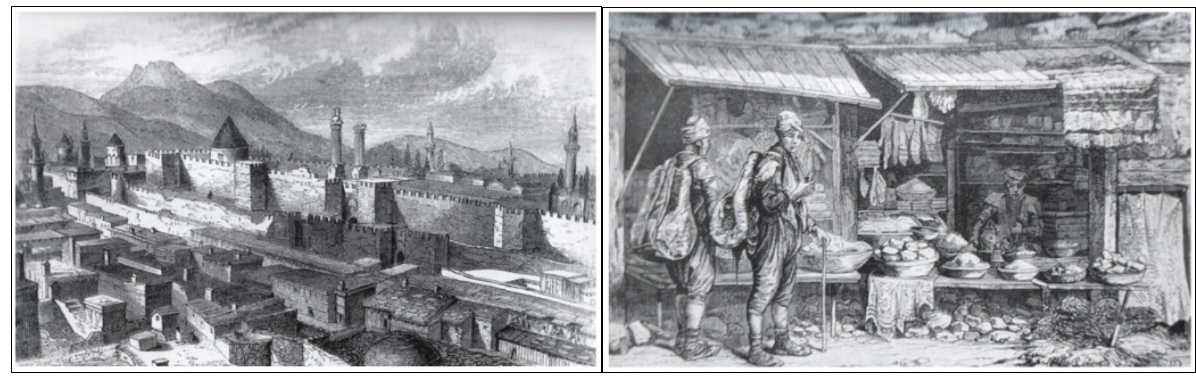

Resim 1. Curzon, Erzurum gravürü (1843); Deyrolle, Erzurum’da bir dükkân gravürü (1869).

1242 yılındaki Moğol yıkımı, şehri harabeye çevirmiş olsa da İpek Yolu çok uluslu ticaretinin devamı neticesinde Erzurum kısa sürede toparlanmıştır (Konukçu, 1992: 61). Nitekim ünlü seyyah Marko Polo XIII yüzyılın ikinci yarısında Venedik ve Cenevizlilerin her zaman uğradıkları önemli bir ticari merkezi olarak Erzurum'u da sayması bunu kanıtlamaktadır (Marko Polo, 1985: 20). Anadolu'nun Moğol İmparatorluğu'nun ekonomik sistemi içerisine dâhil olması, Erzurum gibi doğu bölgelerinin şehirlerinde ticaretinin önemini artırmıştır (Cahen, 1994: 312). Bu ara dönemde cadde çok büyük değişiklikler görmemiş, kısmi tadilat ve batıya doğru eklemelerle ticaret meydanı işlevini devam ettirmiştir. $\mathrm{Bu}$ dönemde Selçuklu yönetimini eline alan Mu'îneddin Süleyman Pervâne (1266-1277) İlhanlılara bağlılığını bildirerek müreffeh ve zengin bir devrin yaşanmasını sağlamıştır (Yuvalı, 2000: 104).

${ }^{5}$ Bkz. Erzurum Arşivi, http://erzurumarsivi.com, (ET: 30.12.2020) Osmanlı Dönemi Erzurum Şehir Haritası. 
Bu nedenle Pervane dönemde Selçuklu Sultanı II. Gıyaseddin Keyhüsrev'in ve Gürcü Hatun'un kızı Aynü'l-Hayat'ın, Pervâne'nin desteğiyle şehrin sembolü haline gelen ve caddenin en önemli belirleyicilerinden olan Çifte Minareli Medrese'yi yaptırdığ da savunulmaktadır (Gürbüz, 2004: 150).

Cumhuriyet Caddesi'nin üçüncü en önemli imarı, şehrin de organik gelişme ile yapılandırıldığı ve ilim yurduna dönüştürüldüğü, İlhanlılar dönemidir (1256-1335). İlhanlılar, Muinuddin Pervane'nin ölümünden (1277) sonra Anadolu'da devlet işlerini umumi valilerin kurduğu "Dalay İdaresi" ile yönetmişlerdir (Kürkçüoğlu, 2007: 114). Erzurum ve çevresindeki Türkmenlerin yerleştirilmesi, çoğunlukla bu dönemde olmuştur (Yuvalı, 2000: 105). Şehir ticari ve nüfus bakımından altın çağını yaşamaktadır (Küçükuğurlu ve Çelik, 2013: 100). Bu dönemde şehrin hemen her yeri imar ve iskân edilmiştir.

Cumhuriyet Caddesi'nin, İlhanlılar döneminde hem güzergâh olarak hem de sınırlama olarak günümüzdeki biçimine yakın bir benzerlikle geliştiği anlaşılmaktadır. Caddenin Tebriz Kapısı'ndan itibaren batıya doğru gelişimi ilk kez iki yakasına inşa edilen abidevi yapılarla sınırlandırılmışıır. Saltukoğulları zamanında Ulu Cami (1179) imarıyla caddenin güney yakası sınırlandırılmış olsa da İlhanlılar döneminde bu sınır günümüze ulaşıncaya kadar bozulamayacak bir imar görmüştür. Ulu Camii'nin hemen doğusuna yapılan ve hem Anadolu'nun en büyük açık avlulu medresesi hem de Erzurum şehrinin simgesi olan Çifte Minareli Medrese (XIII. yy son çeyreği) bu dönemde yapılmıştır (Karamağaralı, 1971: 223). Caddenin güney yakası, Ulu Cami ve bu yapı ile istikamet yönünü tam olarak kesinleştirmiş̧tir. Medresenin hemen karşısında bulunan kapı kulesi aslında caddenin kuzey yakasının ilk belirleyicisi olarak Bizans döneminde yapılmıştır. Kapı kulesinin içerisindeki Ebu İshak-1 Kazeruni (963-1034) Türbesi makamının buraya ne zaman yapıldığı bilinmese de içerisinde Revan muhafızı, Diyarbakır valisi Mürteza Paşa ve Dişlenk Hüseyin Paşa, dışında da Çıldır Valisi kâtibi Mustafa Efendi ile Sultan Abdulmecid Han'ın hariciye müsteşarı Nuri Efendi'nin mezarları da bulunur. Bu kulenin istikametinde aynı düzlem üzerinde İlhanlıların yaptırdığı Cimcime/Çengâl Hatun Kümbeti (1304) aslında caddenin kuzey yakasının da sınırını belirlemiştir (Yurttaş ve Kındığıllı, 2011: 82). Cumhuriyet Caddesi'nin kuzey yakasını belirleyen bir diğer İlhanlı yapısı da Yakutiye Medresesi (1310)'dir. Osmanlı döneminde "Sarayönü" denilen, Lalapaşa Camii'nin doğusunda, günümüzde Menderes Caddesi, dört yol kuzeyi üzerindeki Sultaniye Medresesi ${ }^{6}$ (XIV. yy başları) de (Gürbüz,

\footnotetext{
${ }^{6}$ Sultaniye Medresesi: Birinci Dünya Savaşı'nın başlarına kadar ayakta olan medrese, harp yıllarında yıktırılmıştır. Abdurrahim Şerif Beygu 1592 tarihli Tapu Tahrir Defteri kaydına dayanarak medresenin Selçuklu Sultanı I. Alaaddin Keykubad tarafindan yaptırıldığını belirtmektedir. Abdullah Konyalı da medresenin İlhanlı hükümdarı Gazan Mahmud Han tarafından yaptırıldığını ileri sürmektedir. Genel kanı da eserin İlhanlılar döneminde yapıldığıdır. Kapalı avlulu, revaklı, 18 hücreli ve oldukça önemli bir medrese olan yapının, tekke kütüphane ve bir de mescit ile birlikte kompleks olduğu anlaşılmaktadır. Bkz. Abdurrahim Şerif Beygu
} 
2004: 142), caddenin Bizans sınırlarını aşarak batı yöndeki istikametinin belirleyicisi olmuştur (Konyalı, 1960: 298). İlhanlılar döneminde yapılan bir diğer medrese de Erzincankapı'nın daha batısında aynı isimle bilinen çarşının yanı başında yapılan Ahmediye Medresesi (1314)'dir. Ahmediye Medresesi, caddenin bugünkü istikametinde değil, daha güney kısımdaki eski cadde istikametinde yapılmıştır. Bu dönemde caddenin Erzincankapı istikametinde günümüz güzergâhından güneye doğru kıvrıldığını görmekteyiz. Caddenin, buradaki klasik şehir surlarının batıya açılan sur kapısı Erzincankapı ile "Erzincankapı Çarşısı”nı takip ettiği anlaşılmaktadır.

İlhanlılar döneminde cadde, kale ve surların doğuda ilk inşasında kurulan Tebrizkapı ile başlamakta ve günümüzdeki istikametini küçük kıvrılmalar ile Yakutiye Parkı batısındaki Yukarı Mumcu Caddesi'ne kadar devam ettirmektedir. Buradan güneye kıvrılan cadde, Erzincan kapısından batıya doğru Erzincankapı Çarşısı istikametinde ilerleyerek "Kırkdeğirmenler Deresi” üzerindeki "Fil Köprüsü”ne bağlanmaktadır. Cumhuriyet Caddesi’nin Havuzbaşı-Mumcu arasındaki günümüz istikameti, İlhanlılar döneminde daha güneydeki Erzincankapı Çarşısı güzergâhını takip etmektedir. Ancak bu dönemde Erzincankapı Çarşısının güney yakasında başlayan yapılaşmanın caddenin kuzey yakasında olmadığı anlaşılmaktadır. Caddenin İlhanlılar döneminde şekillenen kullanım biçimi, Osmanlı Devleti'nin son dönemlerine kadar korunarak devam ettirilmiştir.

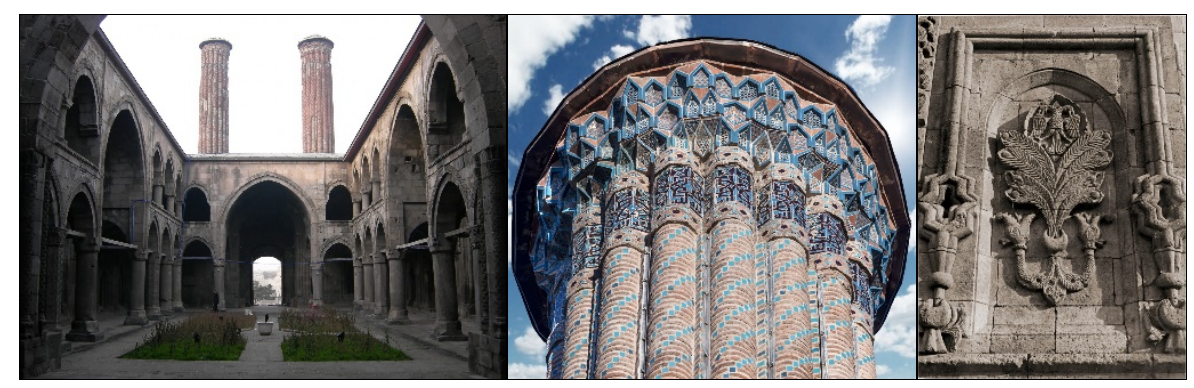

Fotoğraf 4. Erzurum Çifte Minareli Medrese ve detayları.

(1936). Erzurum, Tarihi, Anıtlarl, Kitabeleri, İstanbul: Bozkurt Basımevi, 136; İbrahim Hakk1 Konyalı (1960). Abideleri ve Kitabeleri ile Erzurum Tarihi. İstanbul: Ercan Matbaası, 297. 


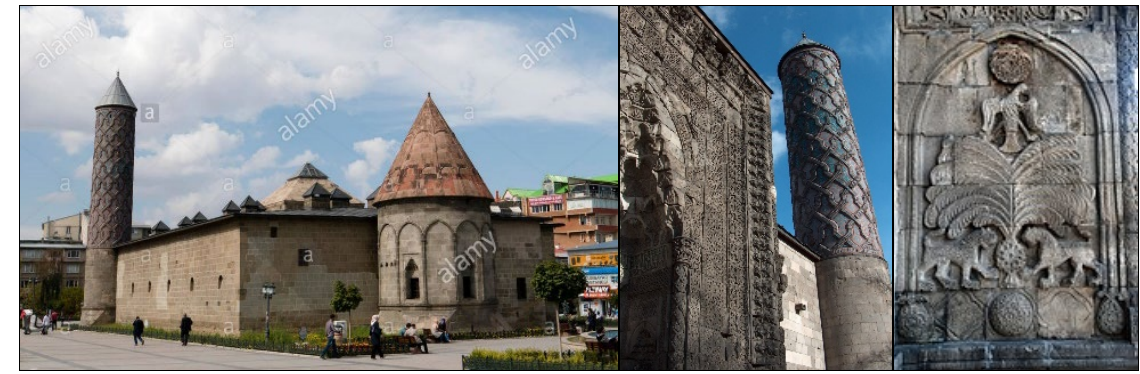

Fotoğraf 5. Erzurum Yakutiye Medresesi ve detayları.

İlhanlılardan sonra; Sutaylılar, Çobanlılar, Eratnalılar, Celayirliler, Akkoyunlular ve Karakoyunlular dönemlerinde sürekli mücadele içerisinde olduğundan halkın refah seviyesi düşmüş ve nüfus azalmıştır (Kürkçüoğlu, 2007: 129). Timur'un, Ankara Savaşı öncesinde, buradan geçişinde Hindistan seferinden getirdiği filleri geçirmek için Kırkdeğirmenler Deresi'ne "Fil Köprüsü”nü yaptırmış olabileceği henüz bir varsayımdan ibaret olsa da 1387 yılında Erzurum'u hâkimiyeti altına aldığında, şehre en büyük tahrip ve yağmalarından birini yapmış olduğu bilinmektedir (Küçükuğurlu ve Çelik, 2013: 101). Günümüzde Bosna Caddesi'ni Çaykara Caddesi'ne bağlayan Filgeçti Köprüsü, her ne kadar bu olaydan adını almış olsa da Timurlular döneminde bu köprünün yeri daha güneyde olmalıdır (Taşyürek, 2016: 191). Timurluların ardından Karakoyunlular ile Akkoyunlular arasındaki uzun süreli mücadeleler, şehrin yıkımını artırmış, cazibesini de kaybetmesine neden olmuştur. Daha sonra Erzurum şehri, Safavî Hükümdarı Şah İsmail tarafından ele geçirilmiş (1502-1514) ve imar edilmiştir. Şah İsmail, Osmanlı Sultanı I. Selim'in 1514 yılında bölgeye gelişi üzerine şehri yağmalayarak çekilmiştir (Konyalı, 1960: 112). Bu dönemde cadde de tahriplerden etkilenmiş, canlılığını kaybetmiş ve yıkıntılar içerisinde kalmıştır (Pamuk, 2007: 129). 

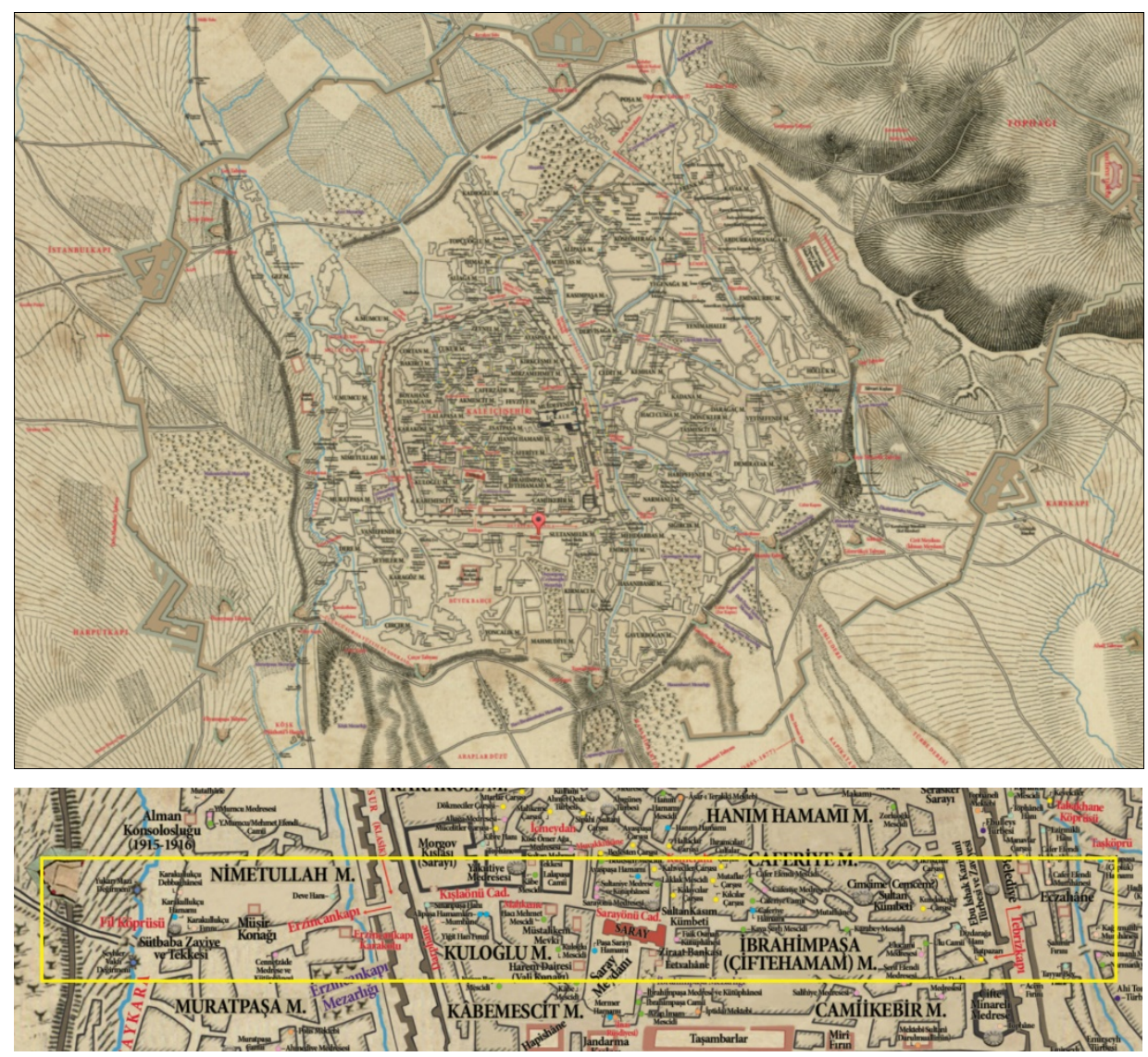

Harita 3. Osmanlı dönemi şehir haritası ve Cumhuriyet Caddesi lokasyonu (Erzurum Arşivi).

\section{B. Osmanlı Hâkimiyetinden Cumhuriyete Kadar, Erzurum Cumhuriyet Caddesi}

Erzurum, Yavuz Sultan Selim zamanında (1512-1520), kesin olmamakla birlikte, 1518-1519 yıllarındaki Mısır Seferi sonrasında Osmanlı hâkimiyetine girmiştir (Aydın, 1998: 51). Her ne kadar bu tarihte Osmanlı hâkimiyetine girmiş olsa da şehrin esas imarı, Kanuni Sultan Süleyman döneminde (1520-1566) 1534 yılındaki I. İran Seferi sonrasında olmuştur. 1535 yılında kurulan Erzurum Beylerbeyliği, bir yandan askerî açıdan, Kafkasya ve İran'a yönelik siyasette en önemli üst haline getirilirken diğer yandan imar faaliyetleri ve şehrin nüfusunun artması, ticaretin canlanması, şehrin mamur olmasını sağlamıştır.

İlhanlılar döneminde, doğuda Tebrizkapısı ile başlayan "Cami-i Kebir Yolu", "Yakutiye Medresesi Meydanı" ile batıdaki "Erzincankapı Çarşısı”na ve oradan da 
Timurlular döneminde yapılan "Fil Köprüsü"ne bağlanan cadde, Osmanlı döneminde güzergâhını benzer bir istikametle korumuştur. Osmanlı Devleti'nin himayesinde uzun yıllar huzur ve refah içerisinde ihya edilen şehrin her bir yanında olduğu gibi cadde de çok sayıda yapı ve şehir donatı elamanlarıyla imar edilmiştir. Tebrizkapı'dan başlayan bu imar faaliyetleri, daha önceden yapılan tarihi abidelerin korunması önceliğinde yeni kurulan vakıflarla zenginleştirilmiştir. Caddenin kuzey yakasında Tebrizkapı sur kapı kulesinin hemen yanında daha önceki dönemlerde yapıldığını düşündüğümüz Ebu İshak

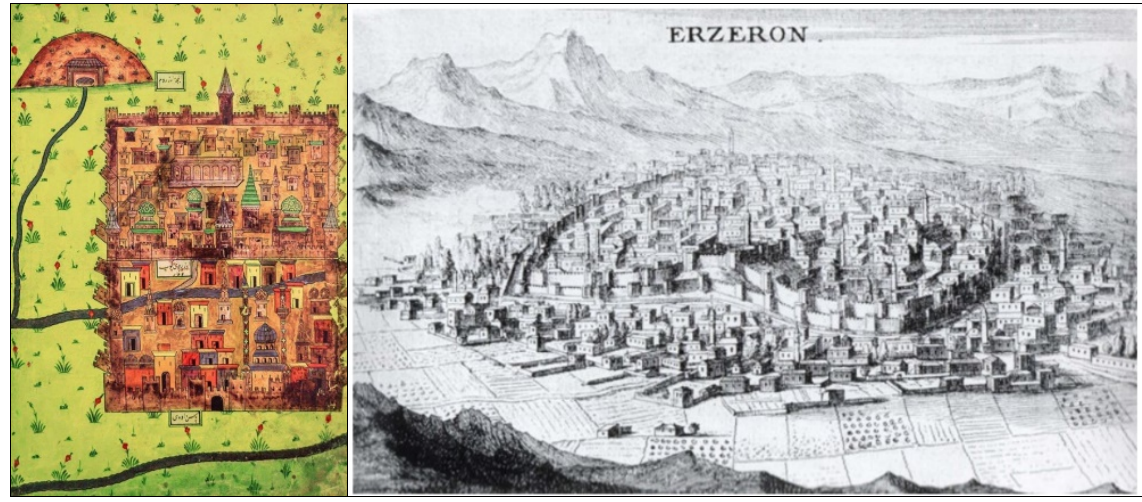

Resim 2. Matrakçı Nasuh, Erzurum minyatürü (1534); Tourneford, Erzurum gravürü (1701).

Kazeruni (963-1034) Türbesi makamına bir zaviye eklenmiş̧ir (Taşyürek, 2010: 29). Zaviyenin hemen yanında geleneksel Erzurum evi tasarımına sahip, Gençağazade Hacı Osman Efendi Konağ ${ }^{7}$ yer almaktadır. Bu konağın yanında iç kaleye doğru giden çarşı ise "çıkrıkçılar çarşısı"” olarak işlev kazanmıştır. Cimcime Hatun Kümbeti ile çıkrıkçılar çarşısı arasında da "kundakçılar çarşısı" yerini almıştır. Caddenin güney yakasında Ulu Camii'nin batısında "Ulu Camii Medresesi”"10 (Küçükuğurlu, 2020: 196) ve "Şerif Efendi Medresesi" "11, cami kuzey beden duvarı hizasından daha kuzeye taşkın olarak yapılmışlardır. Bu iki medresenin daha batısında mutafhanenin tam karşısında

7 Hacı Osman Efendi, Gençağazadeler ailesine mensup emekli bir askerdir. Hacı Osman Efendi'nin oğlu Zakir Bey, 1918-1921 yılları arasında Erzurum Belediyesi başkanlığı yapmıştır. Konak 18. yy. ortalarında; iki katlı, tandırevli ve bahçeli bir plan üzerine yapılmıştır.

8 Çıkrıkçılık: Ahşap malzeme ile küçük ev ve el aletleri, dokuma tezgâhı, su kuyusu mekanizması gibi ağaç işlemesi yapan, ahşap tornacı diyebileceğimiz esnaflıktır.

${ }^{9}$ Kundakçıllk: Kabza, dipçik ve namlu yatağı gibi daha çok savaș aletlerinin ahșap kısımlarını yapan esnaflıktır.

${ }_{10}$ Ulu Camii Medresesi, caminin batı tarafındaki sokağın hemen yanında yapılmıştır. Tam olarak ne zaman yapıldı̆̆ı bilinmese de 18. yüzyıl ortalarına tarihlendirilebilirdir. Medrese, Cumhuriyet Caddesi'nin genişletilmesi sırasında 1924 yılında tamamen kaldırılmıştır.

${ }^{11}$ Ulu Camii Medresesi ile aynı parsel üzerine kurulu olan medrese, 19.yüzyılın ilk yarısına tarihlenmektedir. Medrese Cumhuriyet yıllarında işlevsiz olarak belli bir zaman kaldıktan sonra caddenin yapıldığ 1924 yılında yıkılmıştır. 
da "Salihiye Medresesi"12 yapılmıştır. Mutafhane ${ }^{13}$, Cimcime Sultan Kümbeti batı yanında, caddenin kuzey yakasında mutaflar çarşısının yanında yer almaktadır.

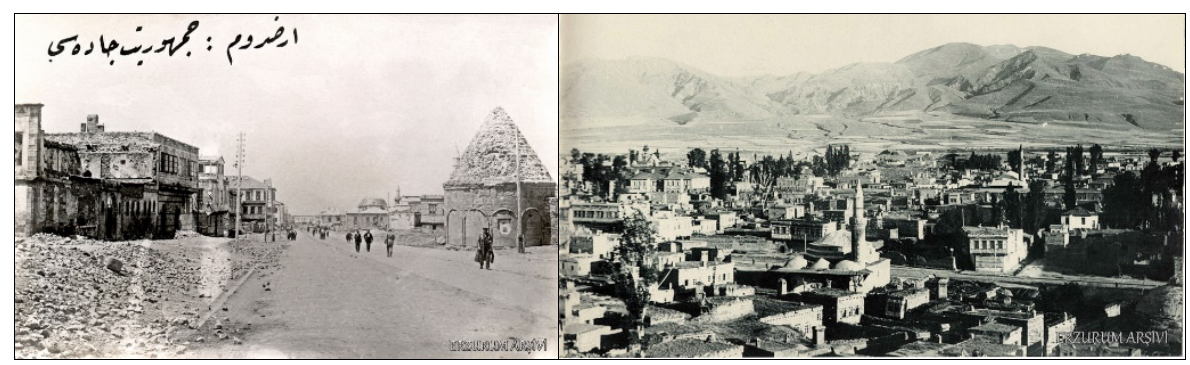

Fotoğraf 6. Cumhuriyet Caddesi’nin 20. yy başlarındaki görünüşü; Caferiye Külliyesi ve güneyindeki caddenin 1930'lardaki görünüşü.

Caddenin kuzey yakasında, mutafhanenin batısında günümüze sağlam bir şekilde ulaşabilen ve Osmanlı külliyelerinden birisi olan "Caferiye Külliyesi" 14 inşa edilmiştir. 1645 yılında tamamlanan külliyenin en doğusunda caminin doğu duvarına bitişik olarak yapılan mektep günümüzde de varlığını korumaktadır (Özkan, 2015: 58). Yol kotunun yıllar içerisinde yükselmesi neticesinde basık kalan caminin batı yönündeki "Caferiye Medresesi" 15 cadde ve sokak genişletme çalışmaları sırasında yıkılmıştır. Medresenin batı yanında külliyenin etrafını dolanarak caddeye bağlanan

\footnotetext{
${ }^{12}$ Salihiye Medresesi, Camiikebir Mahallesi'nde, Memişağa Sokak üzerinde 18. yüzyılın ikinci yarısında inşa edilen medreselerdendir. Bu medrese, Cumhuriyet döneminde uzun yıllar boyunca atık durumda kalmış ve 200 Osmanlı lirasına Halit Aktaş'a satılmıştır. Evkaf idaresinin müdahalesiyle 29 Ağustos 1940 tarihinde bu idareye teslim edilmiştir. Caddenin açılışı sırasında yıktırılmıştır.

${ }^{13}$ Mutafhane: Keçi kılından hayvan çulu, yem torbası, dokunmuş veya örülmüş çul, çuval, yem torbası ya da keçi kılından dokunan yaygı işlerinin yapıldı $\breve{g}_{1}$ imalathane.

14 Caferiye Külliyesi hakkında daha geniş bilgi için bkz. Haldun Özkan (2015). "Erzurum Caferiye Külliyesi ve Restorasyonları, Atatürk Üniversitesi Güzel Sanatlar Enstitüsü Dergisi Journal of the Fine Arts Institute (GSED), S 34. 46-81; Ümit Kılıç (2009), "Erzurum'da Cafer Efendi Vakfi" Atatürk Üniversitesi Türkiyat Araştırmaları Enstitüsü Dergisi, S 41, s.173-187.

15 Caferiye Medresesi: Caminin batısında yer alan medrese yapısı günümüzde tamamen yıkılmıştır. "Vakfiye, medresenin fiziki yapısı hakkında bir bilgi ihtiva etmemektedir. Vâkıf, tövbekâr, ibadetle meşgul ve seyahat edip insanlara iyilikleri tavsiye eden ve fenalıktan men eden talebenin bütün faydalı din ilimlerini burada öğrenmeleri için medreseyi binâ ettiğini ifade etmektedir.1915-16 yılında yapılan yol genişletme çalışmaları esnasında yıktırılmıştır. Cafer Efendi, vakfiyede bu medresede eğitim gören talebeye nâifi ilimler öğretilmesini şart koşmuştur". Her ne kadar vakfiyede medresenin plan ve mimari özellikleri hakkında bir tanımlama bulunmasa da Erzurum'daki diğer Osmanlı dönemi medreselerinin bir benzeri olduğunu düşünmek mümkündür. Genel olarak Erzurum Osmanlı dönemi medreseleri eşit büyüklükte odalara sahip, avlu bağlantılı dışarıya bir giriş ve bir pencere ile açılan mekânlar şeklinde tasarlanmışlardır.
} 
"mutaflar/kılcılar çarşısı"16 devam etmektedir. Caddenin kuzey yakasında mutaflar çarşısının batı yanında da soğuklık-1lıklık ve sıcaklık bölümlerinin tamamını ihtiva eden, "Caferiye Hamamı"17 yer almaktadır. Soğukluk giriş kapısı kuzeye bakan hamamın sıcaklık/halvet bölümü güneye yani caddeye bakmaktadır.

Caferiye Külliyesi'nin tam karşısında caddenin güney yakasında “Kaya Şeyh/Kaya Ağa Mescidi" ${ }^{18}$ yer almaktadır. Bu mescidin doğu tarafina kalan kısımları ile Salihiye Medresesi'nin batı bölümleri üzerinde daha sonradan "Cinisliler Konağı"19 yapılmıştır

16 Mutaflar/Kılcılar çarşısı: Caferiye Külliyesi'nin doğu yönünden kuzey istikametinde ilerlemekte ve cami dış avlusunun etrafını dolanarak medresenin batı yanından caddeye başlanmaktadır.

17 Caferiye Hamamı: “...Hamamlarının en meşhuru, yeni yapılan Cafer Efendi Hamamıdır. Suyu ve havası güzel, içi aydınlıktır.” diye Evliya Çelebi'nin anlatısında gördüğümüz Caferiye Hamamı da medrese gibi yol genişletme çalışmalarında tamamen yıkılmıştır. Cafer Efendi'nin vakfiyesinde hamamla ilgili olarak: “...caminin güneyinde, bahçesinin duvarına bitişik bir şekilde bulunmaktaydı. Güneyi anayol, doğusu Ebubekir Çelebi meskeni, kuzeyi cami bahçesinin duvarı, batısı cami bahçesine giden yol ile sinırlı olan hamam, bi'l-cümle hukuk ve muzafat ile, elbise soyunulacak yeri ile, hücreler ile ve suyu, mensubatı ile bütün eczası ile, geçilecek yerleri ile, oluktan su döküldügü yerler ile, kar atılan mahalleri ile, tavsif edilen ve edilmeyen kendisine ait her hakkı ile câmii ile medreseye vakfedilmiştir." Son y1llarda hamama ait kalıntılara, külliyenin bulunduğu Cumhuriyet Caddesinde yapılan kanalizasyon çalışmaları esnasında rastlanılmış, bunları görenlerin beyanlarına göre birkaç mimari parça da çıkartılmıştır. Ancak Erzurum'la ilgili eski fotoğraflarda hamamın caminin güneyinde değil de batısında olduğuna dair görüntüler bulunmaktadır. Muhtemelen vakfiyede yön tarif edilirken bir karışıklık söz konusudur. Çünkü buradaki mevcut hamamın Caferiye Külliyesine ait olması ve caferiye medreselerinin hemen batısında olması kuvvetle muhtemeldir. Hamamın soyunmalık, 1lıklık ve sıcaklık bölümünden meydana geldiği de vakfiyesinde ayrıca belirtilmiştir. Erzurum'daki diğer Osmanlı dönemi hamamlarının bir benzeri olduğu anlaşılmaktadır. Hamam ve medrese 1916 yılında Osmanlı Harp Heyeti tarafından yıktırılmıştır.

18 VGMA, 1061 Numaral Hurufat Defteri Ramazan 1160 (1747) tarihli belge. Kaya Şeyh/Kaya Ağa Mescidi: Kaya Ağa tarafından 18. Yüzyılın ikinci çeyreğinde yapıldığını düşündüğümüz mescit, Zeki Başar tarafindan da tetkik edilmiştir. Bu mescidin Yayla Palas Oteli yanında olduğunu ve mihrabının da Foto Celal Şengöz'ün fotoğrafhanesinin içerisinde olduğunu ve kendisinin de bu mihrabı gördügünü anlatmaktadır. Bkz. Zeki Başar (1977). Tarih Boyunca Çeşitli Hizmetleriyle Camilerimiz/Erzurum Camileri, Ankara: Atatürk Üniversitesi Yayını, 126.

${ }^{19}$ Cinislilerin Evi, beden duvarlarındaki taş malzemesinin türü ve işçilik üslubu, karışık ve kabarık derzli taş duvar yapımı, hatılların sık düzende atılması, pencere formları yapısı 19. yüzyılın başlarında yapıldığına işaret etmektedir. Yapının eğimli çatı altına alınmış olması ve çatıya tepe pencerelerinin eklenmesi geç dönem özellikleridir. Evin düz dam örtüsünün daha sonraki yıllarda kaldırılarak eğimli çatı altına alındığını semer duvarında kullanılan farklı malzemeden de anlamaktayız. Cinislilerin Evi'nin 1895'li yıllarda genel bir tadilat, 1901 y1lı depreminden sonra ise esaslı bir onarım geçirdiği, 1916 yılına ait eski fotoğraflarından belirlenebilmektedir.

Cinislilerin Evi'nin Rus işgali sırasında Ruslar tarafindan karargâh olarak kullanılan evlerden birisi olduğu bilinmektedir. Milli mücadele döneminde kolordu komutanlığı tarafindan karargâh olarak kullanılan ev, Mustafa Kemal Atatürk'ün Erzurum'a geldiğinde ilk misafir edildiği 
(Sağlam, 2019: 177-189). Günümüzde ön tarafı muhdes dükkânlar ile kapalı olan bu konak, Milli Mücadele'miz adına son derece önemlidir. Gazi Mustafa Kemal Paşa, Erzurum'a geldiği zaman ilk önce bu konakta misafir edilmiştir. Caddenin güney yakasında Kaya Şeyh Mescidi'nin batı yanında, oldukça büyük ve gösterişli yapısı ile "Abdulvahit Paşazade Galib Bey Konağı" 20 bulunmaktadır (Zeynal, 2016: 221). Bu konağın tam karşısında, caddenin kuzey yakasında; tandırevli, iki katlı, iç sofalı ve bahçeli bir plan üzerine, taş işçilikli, cumbalı, ahır merek ve müştemilatı ile "Korukçuzadelerin Konağı" 21 , geleneksel Erzurum evi üslup birliği çerçevesinde inşa edilmiştir. Bu konağın batı yanında "bakkallar çarşısı", daha batıda da "kalaycılar, kazancılar ve kahveciler çarşıları” aynı sokak üzerine arka arkaya sıralanmışlardır.

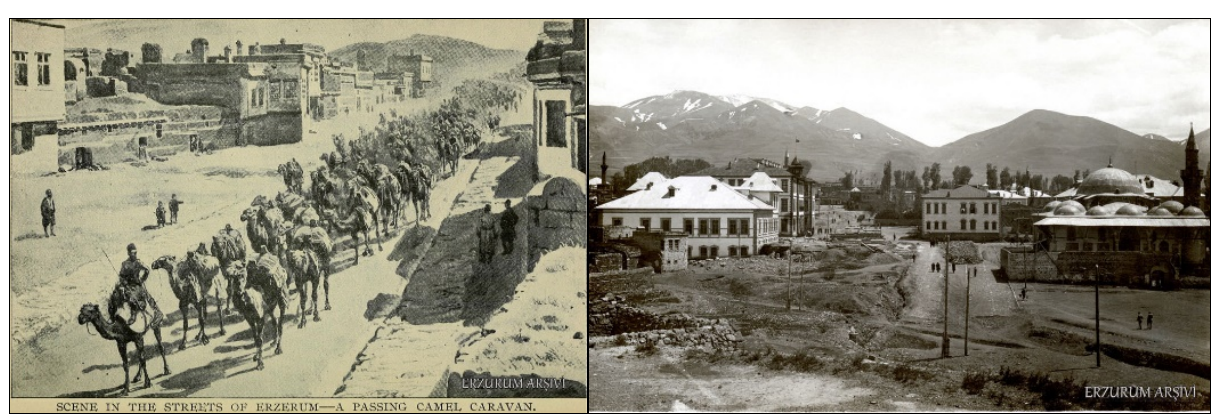

Fotoğraf 7. Erzurum Cumhuriyet Caddesi (1902) ve İç Meydan (1940).

konaktır. 3 Temmuz 1919 tarihinde Erzurum'a gelen Mustafa Kemal Paşa, Müstahkem Mevkii Kumandanlığına ait olan binayı Müfettişlik Karargâhı olarak kullanmıştı. Mustafa Kemal Paşa'nın ordudan ve askerlikten istifasına kadar Milli Mücadele grubunun ilk toplantıları bu karargâh binasında yapılmış, kararlar burada alınmıştı. Bu karargâh binası Cinislilerin Evi'dir. Mustafa Kemal Paşa bu karargâh binasının yakınında bulunan Gözübüyüklerin Evi'nde de ikamet etmekteydi. Bkz: Temel Sağlam (2019), Geleneksel Erzurum Evleri, Restorasyonları ve Ev Yaşantısı, (Yayımlanmamış Doktora Tezi), Atatürk Üniversitesi, Sosyal Bilimler Enstitüsü, 177-189; Mazhar Müfit Kansu (1997). Erzurum'dan Ölümüne Kadar Atatürk'le Beraber, Ankara: Türk Tarih Kurumu Yayınları, 97; Mehmet Önder (1988). Atatürk Evleri- Atatürk Müzeleri, Ankara: Atatürk Araştırma Merkezi Yayını, 34.

${ }^{20}$ Abdulvahit Paşazade Galib Bey Konağı: Konağı, 1913-1914 yıllarında Erzurum Belediyesi başkanlığı yapmış olan Galib Bey'in babası Abdulvahit Paşazade, 19. yüzyılın ilk yarısında yaptırmıştır. Konak çok büyük ve gösterişli bir mimariye sahiptir. 1915 yılında belediye tarafından cadde genişletmesi sırasında "yeniden yapılma sözü" verilerek yıkılmıştır. Her ne kadar kısa süre içerisinde yapımına da başlanmış olsa bile savaş nedeniyle yaptırılamamıştır.

${ }^{21}$ Korukçuzadelerin Konağı: 18. yüzyılın sonlarında yapıldığını tahmin ettiğimiz konak, oldukça büyük bir parsel üzerine inşa edilmiştir. Konağın batıya bakkallar çarşısına bakan bahçe duvarındaki çift yüzlü çeşmesinin iki lüle suyu tapulanmıştır. Çift yüzlü çeşmenin suyunu hem konağın malikleri hem de sokaktan geçenler kullanabilmektedir. Konağın tandırevindeki kurunlu çeşmesine de bağlanan temiz su, Palandöken Dağı kaynaklıdır. 
Osmanlı döneminde Cumhuriyet Cadde'sini ve şehri etkileyen en önemli imar faaliyeti "Beylerbeyi Sarayı"22 inşasıdır. Saray, caddenin güney yakasında günümüzdeki Aliravi Caddesi üzerinde, Bölge İdare Mahkemesi, Yakutiye Belediyesi ve bir özel eğitim kurumu olan İlkokul binalarını da kapsayan oldukça büyük bir alan üzerine, 16. yüzyılın ikinci yarısında yaptırılmıştır (Küçükuğurlu, 2018a: 24). Sarayın hemen önünde, 1558-59 yılında Ayas Paşa tarafından genişletilen caddeye, sarayın inşasından sonra "Sarayönü Yolu/Caddesi" denilmiştir (Küçükuğurlu, 2018a: 25). Bu sarayın etrafında daha sonraları birçok paşa sarayı ve köşk inşa edilmiş, çeşitli çarşılar kurulmuş ve Cami-i Kebir merkez çekim noktası buraya evrilmiştir.

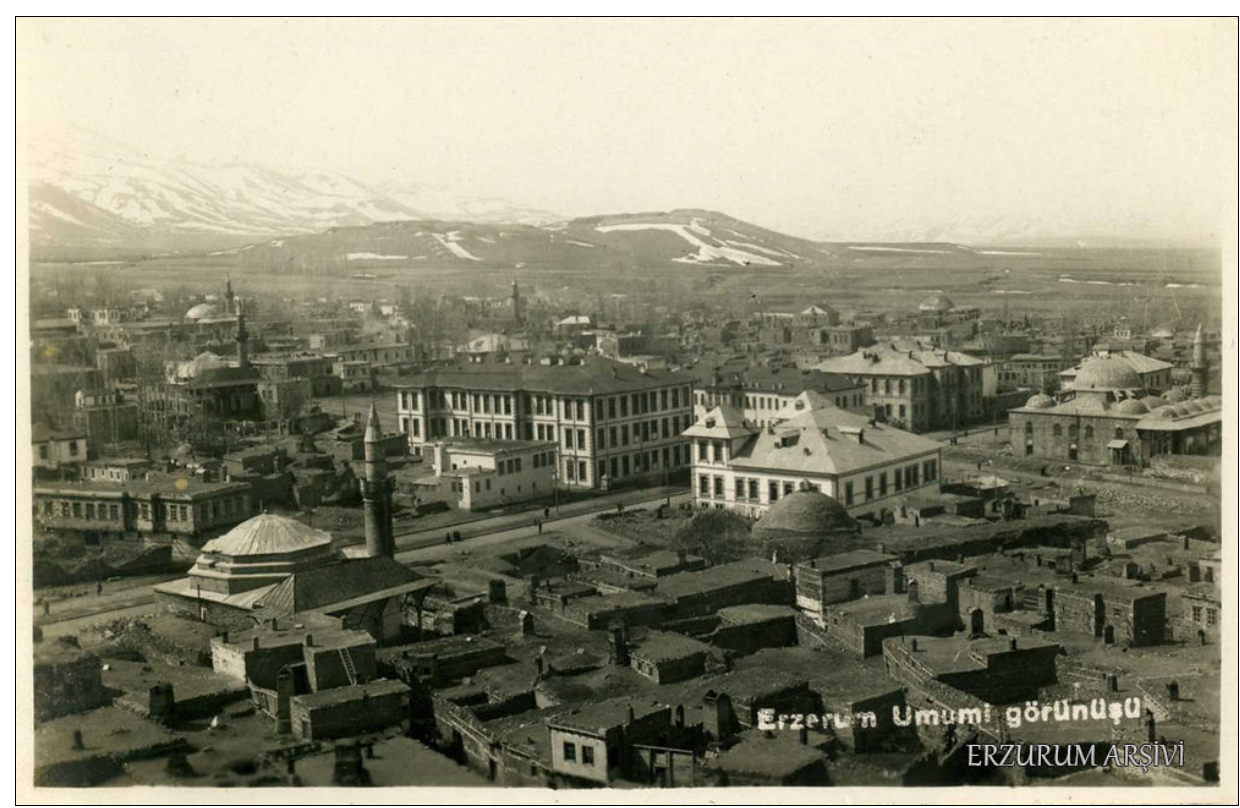

Fotoğraf 8. Erzurum Cumhuriyet Caddesi ve Sarayönü yapılaşması.

Beylerbeyi Sarayı'nın 19. yüzyılda ayakta olduğu, kaynaklardaki anlatımlardan anlaşılmaktadır ${ }^{23}$. Beylerbeyi Sarayı yıkıldıktan sonra, kurulduğu alanın bir kısmında,

22 Beylerbeyi Sarayı: Sarayın Kanuni Sultan Süleyman ya da düşük bir ihtimalle II. Selim Tarafından yaptırıldığı düşünülmektedir. Evliya Çelebi, sarayın çok katı olduğunu, 110 odası, iki katlı divanhaneleri, yüksek kasırları ve irem bağlarını andıran gül bahçelerinin varlığından söz etmektedir. Sarayın güneyinde Yenikapı surlarına kadar giden saray meydanında cirit oynandığını da aktarmaktadır. Saray doğu-batı uzantılı dikdörtgen bir alan üzerine oturmaktadır. Sarayın giriş kapısı (divan kapısı) caddeye doğru bakmaktadır.

${ }^{23}$ Bkz. Aleksandr Puşkin (2008). Erzurum Yolculuğu, (Çev. Ataol Behramoğlu), İstanbul: Türkiye İş Bankası Kültür Yayınları. 
1889 y1lında "Valilik Konağı""24 (Cumhuriyet Oteli/özel bir İlkokul), "Hükumet Konağı" (Günümüzde Bölge İdare Mahkemesi), bir kısmında Mevki-i Müstahkem Askeri Komutanlık" (Günümüzde Yakutiye Belediyesi) binaları 1902 yılında yapılmışlardır. Hükümet Konağı, 1916 Rus işgalinde yakılmış ve harap haldeyken 1924 yılında Cumhuriyet döneminde esaslı bir onarım geçirerek 1986 yılına kadar "Hükumet Konağı" olarak kullanılmaya devam etmiştir.

Beylerbeyi Sarayı'nın karşısına, Lalapaşa Camii doğusuna Sarayönü ya da "İç Meydan" denilmektedir. Bu alana, kalaycılar çarşısının hemen batısına "Sultan Kasım Kümbeti", "Dervişağa Medresesi", "Sarayönü Dairesi”, muvakkithane, altı koğuşlu jandarma kışlası, hükumet konağı mahzeni, polis dairesi ve istihkâm binaları (Küçükuğurlu, 2008: 67) Osmanlı dönemi yapıları olarak eklenmiştir. Osmanlı döneminde çok canlı olan iç meydan, Osmanlı-Rus savaşları neticesinde bu canlılığını kaybetmiş, birçok yapı yıkılmıştır. Bu cümleden olarak; İlhanlılar döneminden kalma Sultaniye Medresesi ve Osmanlı dönemindeki "Hallaçlar Çarşısı"25 ile İbrahim Paşa Vakfi'na ait otel, firın, çayhane ve 7-8 büyük dükkân, savaş yıllarında harap olmuştur. Dönemdeki adı; "Ayaspaşa Yolu”, "Sarayönü" ya da "iç meydan” olan Cumhuriyet Caddesi'nin kuzey yakasında, Yakutiye Medresesi'nin doğu tarafinda 1562 yılında yaptırılan Lala Mustafa Paşa Külliyesi'nden ${ }^{26}$ günümüze yalnızca cami gelebilmiştir. Cami, mektep ve hamamdan oluşan külliyeye 1836 yılında muvakkithane de eklenmiştir. Mimar Sinan'ın planladı̆̆ı caminin tam karşısında caddenin kuzey yakasında, günümüzdeki Yakutiye Belediyesi binasının batı tarafında Osmanlı döneminde "Faik Osman Kütüphanesi"27 ve sarayönü fırını bulunmaktadır. Sarayönü

${ }^{24}$ Paşa Sarayı/Valilik Konağı/Cumhuriyet Oteli: Beylerbeyliği Sarayı'nın güney tarafında bulunan bu sarayın Beylerbeyinin özel ikametgâhı olduğunu 1828-29 Osmanl1-Rus savaşında Rus ordusu ile birlikte Erzurum'a gelen ünlü Rus yazar Aleksandr Puşkin'in anlatılarından çıkarabilmekteyiz. Puşkin, sarayın çok büyük ve gösterişli yapısını ve çok sayıda odasının varlığının yanında selamlık- haremlik kıstasına uygun yapıldığını da aktarmaktadır. Sarayın has ahırları, müştemilatı ve çok süslü bahçesinden uzun uzun bahsedilmiştir. Doksan üç harbinde (1877-78) kullanılamaz hale gelen saray, daha küçük boyutlarla valilik konağı olarak yaptırılmıştır. Bkz. Aleksandr Puşkin (2008). Erzurum Yolculuğu, (Çev. Ataol Behramoğlu), İstanbul: Türkiye İş Bankası Kültür Yayınları.

Konak 1889 yılında, Beylerbeyi Sarayı yıkılmazdan önce, harem dairesinin arsasında, Erzurum Belediyesi tarafından valilerin ikametgâhı olarak yaptırılmıştır. 1926 yılında Valilik Konağı'nın Gureba hastanesi karşısına (Tatbikat İlkokulu) taşınması ile Cumhuriyet Oteli olarak kullanılmıştır. 1939 yılında da Erzurum Belediyesi Meclis kararıyla üzerine bir gazino ilave edilmiştir. 1953 yılında Vakıflar İdaresi'ne devredilmiştir.

${ }^{25}$ Hallaç: Yün ve pamuk işi ile uğraşan esnaflara verilen addır.

${ }^{26}$ Daha geniş bilgi için bkz. Hamza Gündoğdu (1992). Erzurum Lala Paşa Külliyesi, Ankara: Kültür Bakanlığı Yayınları.

${ }^{27}$ Faik Osman Kütüphanesi: Köse Ömer Ağa'nın oğlu olan Faik Osman Efendi, 1795 yılında sarayönündeki konağının bir bölümünü kütüphaneye dönüştürmüş ve idamesi için de vakfiye kurmuştur. Kütüphanenin bir de dershanesi bulunmaktaydı. Kütüphanedeki kitapların çoğu, 
firınının batı yanında "Kazan Bey/Hacı Mehmed Mescidi"28 Osmanlı döneminde yapılan erken tarihli ibadethanelerden biridir. Mescidin batı yanında geleneksel Erzurum evi ${ }^{29}$ özelliği taşıyan konaklar dizilidir. Bu konaklardan günümüzdeki İbrahim Erkal Kültür Merkezi'ne en yakın olanı, söylenim biçimi nedeniyle zamanla "Hannana Paşa" ${ }^{30}$ olan Hanım Ana Konağıdır (Sağlam, 2019: 1049).

Günümüzde İbrahim Erkal Kültür Merkezi olarak kullanılan ada, Osmanlının erken dönemlerinde şehir içi hanı olarak kullanılmıştır. "Kibreli/Gübreli Han"31 adı ile bilinen hanın yakınlarında bir de han fırını bulunmaktadır. 1829 Rus işgali ve depremlerle yıkılan hanın yerinde 1860 yılında Morgov Topçu Kışlası'nın top ambarları yapılmıştır. Ambarların yıkılması ile burada kurulan Tebrizcikli Ömer Paşa Vakfı'na (Küçükuğurlu, 2008: 355) ait dükkânlar yapılmıştır. Önündeki meydan ise uzun süre aynı işlevle ticari pazar olarak kullanılmıştır.

Cumhuriyet Caddesi'nin belirleyicilerinden olan Yakutiye Medresesi etrafında şekillenen çok sayıda Osmanlı dönemi yapısı vardır. Meydana, Lalapaşa Camii’nden sonra yine Kanuni Sultan Süleyman döneminde Paşa Sarayı yaptırılmıştır ${ }^{32}$. Paşa sarayı Yakutiye Medresesi'nin kuzeybatısında yaptırılmış olmalıdır. Bu saray, daha sonraki

Erzurum hattatları tarafından yazılmış kıymetli eserlerdi. Erzurum ulemasından Solakzade Ahmed Efendi'nin oğlu Muhammed Hamid Efendi hem kütüphane sorumlusu hem de dershanenin müderrisi olarak görev yapmıştır. Bkz. Erzurum Tapu Sicil Arşivi, Köse Ömer Ağazade Faik Osman Vakfiyesi.

${ }^{28}$ Mescid, Kazgan Bey Mescidi olarak 16. yüzyılın sanlarında yapılmış olmalıdır. Bu mescidin 1859 yılı depremi sonrasında yıkıldığı ve Hacı Mehmed tarafindan yeniden yapıldı̆̆ düşünülmektedir. 1937 yılında kadro verilmeyerek satışa çıkarılan bu mescidin yerinde daha sonraları çay bahçesi yapılmıştır.

29 Daha geniş bilgi için bkz. Haşim Karpuz (1984). Türk Mesken Mimarisinde Erzurum Evleri, Ankara: Kültür Bakanlığı Yayınları; Temel Sağlam (2020) "Gelenekli Erzurum Evleri", Şehr-i Kadim Aziziye Edebiyat-Tarih-Kültür-Sanat Dergisi, Say1 17, 76-86.

30 Hannana Paşa Konağı: Kuloğlu Mahallesi (Murat Paşa Mahallesi), Bahçeler Sokak ile Cumhuriyet Caddesi'nin kesiştiği yerde, Katipzade Mehmet Efendi tarafından 19. yüzyılın ikinci yarısında yaptırılan konağa Mehmet Efendi'nin eşi olan Ana Hanım Paşa'nın adı verilmiştir. İki katlı ve bahçeli olarak yapılan konağın taş işçilikli cepheleri geleneksel mimari düzeninde yapılmıștır. Konağın zemin katı tandırevli, üst kat da iç sofalı plan tipinde inşa edilmiştir. Hanım Ana bu konağı Kızılay'a bağışlamış ve yıkılarak yerine Kızılay Yurdu yapılmıştır.

${ }^{31}$ Gübreli Han: 17. yüzyılda yapıldığını düşündüğümüz han, Osmanlı şehir içi hanları planında yapılmıştır. Hanın önünde çok büyük bir meydanın olduğu anlaşılmaktadır. Erzincankapı istikametinden gelen yolcuların hayvanları ile birlikte kalabildikleri ve meydanda ticaret yapabildikleri hatırı sayılır büyüklükteki han yakınındaki fırın ve diğer dükkânlarla işlek bir yerdi.

32 Daha geniş bilgi için bkz. Abdurrahim Şerif Beygu (1936). Erzurum, Tarihi, Anıtları, Kitabeleri, İstanbul: Bozkurt Basımevi, s. 150; İbrahim Hakkı Konyalı (1960). Abideleri ve Kitabeleri ile Erzurum Tarihi. İstanbul: Ercan Matbaas1, s. 302; Mustafa Polat (19 Haziran 1957). "Yakutiye Camiinin Düşündürdükleri”, Hür Söz Gazetesi; Murat Küçükuğurlu (2013). Erzurum Tabyaları ve Kışlaları, İstanbul: Mas Matbaacılık, s. 219-220. 
yıllarda yeniden işlevlendirilerek onarımlarla askeri kışlanın bir parçası olarak kullanılmıştır. Medresenin güneybatısına, cadde ile medrese arasına, 1796 yılında Vali Yusuf Ziya Paşa tarafından topçu kışlası yaptırılmıştır. "Morgov Kışlası" 33 adı ile bilinen kışla, medreseye geçit veren büyük bir kemer açıklığı ile iki blok halinde yapılmıștır. Kıșla, farklı askeri birlikler tarafından kullanılmış ve 1940'lı yıllarda batı tarafına yeni askeri bina eklemeleri olmuştur.

İlhanlılar döneminde olduğu gibi cadde, Osmanlı döneminde de güney yakasındaki Gübreli Hanın batı yanından güneye, Erzincankapı Çarşısı'na ulaşmaktaydı. Çarşı, batıya açılan Erzincankapı sur kapısı kuleleri ile başlamaktadır. Çarşının güney yakasında kapı kulesinin hemen batı tarafinda "Erzincankap1 Mezarlı̆̆ı" 34 yer almaktadır. Çarşının kuzey yakasında kapı kulesinin batı tarafında oldukça büyük bir parsel olan "Cennetzade Vakfi"na" ${ }^{35}$ ait alan ve yapılar bulunmaktadır. Alanın doğusunda "Cennetzade Kütüphanesi”, kütüphanenin batısında "Cennetzade Medresesi”, medresenin batı yanında da bahçeli ve iki katlı "Cennetzade Konağı” yer

${ }^{33}$ Morgov Kıșlası: Gürcistan Meliki olan Morgov/Marav Han, İran Şah’1 I. Abbas ile olan mücadeleleri nedeniyle Osmanlı Devleti ile iletişim kurmuş ve İstanbul'da Müslüman olarak Mehmed adını almıştır. Abaza isyanı sırasında Erzurum'da büyük fedakârlıklar gösteren Morgov Han'ın adını yaşatmak için kışlaya bu ad verilmiştir. Morgov Kışlası, 1829 Rus işgali sonrasında yıkılmış, 1832 yılında Erzurum valisi Esat Muhlis Paşa tarafından tekrar yaptırılmıştır. 1859 depreminde harap olan kışla, vali Arif Paşa tarafından 1860 yılında tekrar yaptırılmıştır. 1928-34 yıllları arasında 3. Topçu Alayının karargâhı olarak kullanılan Morgov Kışlası, İkinci Dünya Savaşı sırasında 3. Ordu Ölçme Taburu'na verilmiștir. Daha sonra Merkez Komutanlığı'na tahsis edilen kışla, batı kısmına yapılan ilavelerle 3., 9., ve 29. Tümen Karargâhları olarak kullanılmıştır. Kışlanın, Yakutiye Meydanı açılması kararı ile 1977 yılında yıkımına başlanmış ise de yıkım durdurulmuş ve ancak 1979 yılı Kasım ayında tamamen yıkılabilmiştir. Bkz. Murat Küçükuğurlu (2013). Erzurum Tabyaları ve Kışlaları, İstanbul: Mas Matbaacılık, s. 218-249.

${ }^{34}$ Erzincankapı Mezarlığı'nda: Çifte Minareli Medrese müderrisi Ebubekir El-İspiri (ö: 1713), Habib Efendi'nin talebesi ve Aşağı Mumcu Camii kürsü şeyhi Eyyub Efendi (ö: 1721), Ali Ağa Medresesi Müderrisi ve Lala Paşa Camii kürsü şeyhi Zeynüddin Mustafa Cemal Efendi (ö: 1888), İbrahim Paşa Camii kürsü şeyhi Solakzade Ahmed Tevfik Efendi (ö: 1895), Ömer Fazıl Efendi'nin kardeşi hal ehli Necmüddin Muhammed Rıza Efendi (ö: 1905) gibi önemli şahsiyetlerin mezarları vardı. Bkz. Muzaffer Taşyürek (2010). Erzurum Türbeleri ve Ziyaret Yerleri, Erzurum: Palandöken Belediyesi Kültür Serisi 3, s. 136.

${ }^{35}$ Cennetzade Vakfi: Cennetzade ailesinden Erzurum kadısı Abdullah Edip Efendi, 1847 tarihli bir vakfiye kurmuştur. Kendi ikametgâhı olan bahçeli iki katlı ve çıkma cepheli büyük konağın hemen doğusuna bir medrese, medresenin yanına da kütüphane yaptırmıştır. Büyük konağın içerisinde ahırlar ve mereği de olan havuzlu bahçeleri leylak ağaçları ile daha da güzelleştirilmişti. Cennetzadelerin Köşü̈ de bu alan içerisinde daha kuzey tarafta yer almaktaydı. Üç odalı ve büyük bir dershanesi olan medresesin sorumlu müderrisi aynı zamanda kütüphaneden de mesuldü. Cennetzade Vakfina ait olan bu yapılar, 1941 yılında belediye tarafindan istimlak edilmiştir. Bkz. Murat Küçükuğurlu (2020). Erzurum Camileri Medreseleri Kütüphaneleri, Konya: Çizgi Kitabevi, s. 184-185. 
almaktadır. Cennetzadelerin arazisinin batı yanında 19. yüzyılda yapılmış çok büyük bir "Müşir Konağı" 36 bulunmaktadır. Müşir Konağı'nın karşısında, çarşının güney yakasında, Ahmediye Medresesi'nin batı yanında 1573 yılında Beylerbeyi Murat Paşa tarafından yaptırılan "Muratpaşa Camii" ${ }^{37}$ ve meydanı yer almaktadır. Caminin batı tarafında çarşı caddesine daha yakın olan alan üzerinde "Sütbaba Zaviye ve Tekkesi" 38 bulunmaktadır. Erzincankapı Çarşısı'nın kuzey yakasında, Müşir Konă̆ı'nın batı yanında "Karakullukçuların"39 firını, hamamı ve debbağhânesi 20. yüzyılın ortalarına kadar varlığını devam ettirmiştir.

Erzincankapı Çarşısı, batıda Kırkdeğirmenler Deresi üzerindeki "Şeyhler Vakfı Değirmeni" ile "Yukarı Mazî Değirmeni”"40 arasındaki Fil Köprüsü ile batıya geçmekte ve kuzeye dönerek İstanbulkapı ile bağlanmaktadır.

\section{Cumhuriyet Sonrasinda, Erzurum Cumhuriyet Caddesi}

I. Dünya Savaşı'nın ardından Rusların ve Ermenilerin yıkımları neticesinde harabeye dönen Erzurum şehri, Cumhuriyet döneminde esaslı bir imar görmüştür. Kâzım Karabekir Paşa'nın gayretleriyle Millî Mücadele döneminde önemli imar faaliyetleri yürütüldüğü anlaşılmaktadır. Öncelikle muhacirlikten dönen ve kırsal kesimden şehre gelen halkın ikametgâhı için gereken tedbirler alınmış ve 1920 yılı itibariyle şehrin imarının neredeyse tamamlandığı belirtilmiştir (Karabekir, 1993: 66). Ayrıca bu yıllarında devlet idaresinin devamını sağlamak için acil olarak kamu binaları ya yenilenmiş ya da yeniden yaptırılmıştır. Bu meyanda cadde üzerinde bulunan Hükümet Konağı (Bölge İdare Mahkemesi) ve Mevkii Müstahkem Binası (Yakutiye Belediyesi), 1920-21 yıllarında yeniden yaptırılmıştır. 20 Nisan 1920 tarihi “Ağaç

\footnotetext{
${ }^{36}$ Müşir Konağı: İki katlı, plaster cepheler ile batılı üslup ile yapılmıştır. Günümüzdeki AVM ile Kızılay İş Hanı arasında kalan alan daha sonra konaklarla doldurulmuştur.

${ }^{37}$ Daha geniş bilgi için bkz. Barış Aydın (2014). "Osmanlı Dönemi Erzurum Murat Paşa Cami”, Akademik Sosyal Araştırmalar Dergisi, Y11: 2, Say1: 7, s. 152-160.

${ }_{38}$ Bkz. Erzurum Arşivi, http://erzurumarsivi.com, (ET: 30.12.2020) Osmanlı Dönemi Erzurum Sehir Haritas1.

${ }^{39}$ Karakullukçu tabiri, hizmetlerinde bulundukları yeniçerilerin aynı zamanda kul adıla anılmış olmasına dayanır. "Onlara hizmet eden" anlamında kullukçu ve yaptığı işin bir ayak hizmeti olması dolayısıyla karakullukçu şeklinde adlandırılan bu görevlilerin ayrıca inzibat noktalarında görev yaptıkları bilinmektedir. Bu hizmet zamanla ön plana çıkarak asayiş ve güvenliği sağlayanları ifade eder bir anlam kazanmıştır. Karakullukçular yerleri süpürürler, kıdemli yeniçerilerin ayakkabılarını temizlerler, yemek kaplarını yıkarlar, odun yararlar, kandilleri yakarlar ve alışveriş için pazara giderlerdi. Sadece kullukçu diye de anılan bazı karakullukçuların koğuş dışı görevlerinin başında İstanbul'da ve taşradaki karakollarda inzibat ve asayişi sağlama işi gelirdi. Bkz. Abdulkadir Özcan (2006). "Karakullukçu”, TDV Ansiklopedisi C 24, s. 438-439. Erzincankapı Çarşısı yakınlarındaki karakullukçuların yapıları, 1911 yılında maliye adına tapuya kaydedilmiş, daha sonra Kızılay’a devredilmiştir.

${ }^{40}$ Bkz. Erzurum Arşivi, http://erzurumarsivi.com, (ET: 03.0.12021) Osmanlı Dönemi Erzurum Şehir Haritası.
} 
Bayramı" olarak ilan edilmiş ve şehrin muhtelif alanları ile birlikte cadde de ağaçlandırılmıştır.

Cumhuriyet Caddesi'nin kesintisiz olarak açılması ve ana cadde haline getirilme

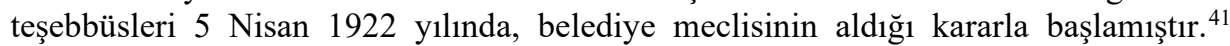
Vilayete sunulan bu karar, vilayet idare meclisi ile belediye meclisinin ortak çalışmaları neticesinde caddenin 25 metre genişliğinde olması kararı ile kabul edilmiştir. Ancak daha sonra cadde üzerinde bulunan eski eserlerin muhafazası için bu genişlik 20 metreye çekilmiştir. 1924 yılına kadar Erzincankapı ile Tebrizkapı arasındaki kısım, bazı eksiklerle birlikte tamamlanmış ve 13 Eylül 1924 yılı depremi sonrasında 30 Eylül'de Erzurum'a gelen Gazi Mustafa Kemal tarafından açılışı yapılmıştır. Caddenin açılış töreninde belediye başkanı Nazif Bey'in: "Gazi Mustafa Kemal Caddesi" isminin verilmesi, halkın genel arzusudur." şeklindeki teklifine karşılık Gazi: "Ben faniyim, ama Cumhuriyet ebediyen yaşayacaktır. Caddeye "Cumhuriyet" adının verilmesi daha uygun olur." demiştir. Böylece Erzurum şehrinin kuruluşu ile yaşıt olan ana caddesi, resmi olarak "Cumhuriyet Caddesi” adını almıştır.

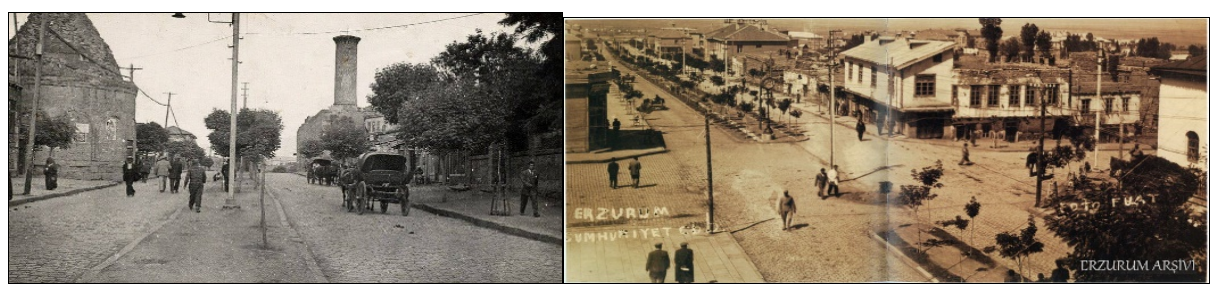

Fotoğraf 9. Cumhuriyet Caddesi doğu ve batı tarafının görünüşü.

Vali Zühtü Bey'in (1923-1931) öncülüğünde, caddenin merkezi olan Hükümet Konağı etrafında "I. Ulusal Mimari” üslubuyla çok sayıda bina yapılmıştır. Lalapaşa Camii batısına, Morgov Kışlası'nın doğusuna "Erzurum Kimyahanesi”42, kimyahanenin tam karşısında bulunan ve savaş yıllarında yıkılan yapıların bulunduğu alana, oldukça büyük bir "şehir kütüphanesi" inşa ettirilmiştir. Kütüphane binası amacının dışında IX. Kolordu Karargâhı olarak kullanılmıştır (Erzurum Gazetesi, 28 Birinci Kanun 1931). 1940 yılında Kolordu'nun Havuzbaşındaki yeni binasına taşınması neticesinde İl Özel İdaresi tarafından kullanılmış ve daha sonraları da yıkılmıştır. Bu binanın yerinde günümüzde Özel İdare İş Hanı bulunmaktadır. Günümüzdeki Yakutiye Belediyesi binasının hemen üzerinde yer alan ve özel eğitim

$41 \mathrm{Bu}$ kararda, caddenin Erzincankap1-Tebrizkap1 arasına "Cumhuriyet Caddesi”, YenikapıArdahankapı arasında da İstasyon Caddesi denilmesi kararlaştırılmıştır. Henüz Cumhuriyetin ilan edilmemiş olduğu bu yıllarda caddeye isminin verilme kararı, aslında halkın yönelimini göstermektedir. Bkz. Erzurum Belediyesi Arşivi, Meclis Zabıtları, 11 Nisan 1931.

${ }^{42}$ Kimyahane olarak yapılan bu binanın üzerine 1930 yılında bir kat daha ilave edilerek işlev yenilemesi yapılmış ve bina "Posta ve Telgraf Müdürlügü" olarak kullanılmıştır. 1977 yılında Yakutiye Meydanını açma projesi ile Morgov Kışlası ile birlikte sökülerek ortadan kaldırılmıştır. 
kurumu olarak kullanılan okul binasının yerindeki "Cumhuriyet Oteli" de Eylül 1926 yllında bu mimari üslupla yenilenmiştir. Caddenin kuzey yakasında Lalapaşa Cami doğusunda, Hükümet Konağı'nın kuzeyinde Sultaniye Medresesi ve İbrahim Paşa Vakfiyesine ait dükkânların yerinde 1926 yılında Belediye Hizmet Binası inşasına başlanmıştır. 1929 yılında tamamlanan Erzurum Belediyesi binasına 1947 yılında bir kat daha ilave edilmiştir. 1964 yılında yıkılma tehlikesi olan bina yıkılarak aynı yerine 1977 yılında yenisi yapılmıştır (Küçükuğurlu, 2008: 359). Sümerbank olarak da kullanılan binanın yerinde şimdilerde çok katlı SGK binası bulunmaktadır (Zeynal, 2016: 220). Bu dönemde inşa edilen bir diğer yapı da yeni dönemin genel tercihini temsil eden sembol eserlerden olan "Cumhuriyet Sineması"dır". Cumhuriyet Sinemasi, caddenin güney yakasında Erzincankapı doğusunda, Kuloğlu Mahallesi’nde, Gübreli Han'ın yerindeki tophane ambarları ve Tebrizcikli Ömer Paşa Vakfı'na ait olan dükkânların yerinde yapılmıştır.

Cumhuriyet Caddesi üzerindeki bir diğer faaliyet de: 1929 yllında Cumhuriyet Sineması'nın caddeye bakan, harap haldeki ön kısmının, etrafı demir şebekeli parmaklıklarla tanzim edilerek park haline getirilmesidir. Yine aynı yılda, Muratpaşa Cami önündeki bahçenin savaş yılları ve sonrasındaki tahribatı, tadil edilerek park haline getirilmiştir. Hükümet Konağı ile Lalapaşa Camii arasındaki dört yol kavşağı üzerine 1930 yılında "Gazi Heykeli”"44 yapma kararının alınması ve heykelin kaidesinin konulması da cadde üzerindeki değişikliklerdendir.

43 Cumhuriyet Sineması: 1925 yılında inşasına başlanan sinema binası 1926 yılında tamamlanmıștır. Yaklașık olarak 100000 liraya mal olan sinema binasına ilin idarecileri çok öncelikli bir önem vermişlerdir. Sinema 5-6 Mayıs 1931 gecesi çıkan yangında kullanılamaz hale gelmiștir. Daha sonra sinema yeniden yapılmıș ve adı da "Saray Sineması" olarak değiştirilmiştir. 14 Kasım1960' ta sinema tekrar yanmış ve sonradan yeniden yaptırılarak adı "Dadaş Sineması" olarak değiştirilmiştir. Daha sonra AVM ve spor salonu olarak kullanılan yapı günümüzde "İbrahim Erkal Kültür Merkezi" adıyla hizmet vermektedir.

${ }^{44}$ Her ne kadar 1930 yılında heykel kaidesi konulmuş ise de "Şaha Kalkmış At Üzerinde Gazi Heykeli" bir türlü yapılamamıştır. Kaide daha sonraki yıllarda zafer takı biçimine dönüştürülmüş ve Menderes ve Ali Ravi Caddeleri ile birleșimi sırasında yerinden kaldırılmış ve döner kavşak konulmuştur. Daha sonraki yıllarda caddenin şerit artırımı nedeniyle döner kavşak da kaldırılmıştır. 


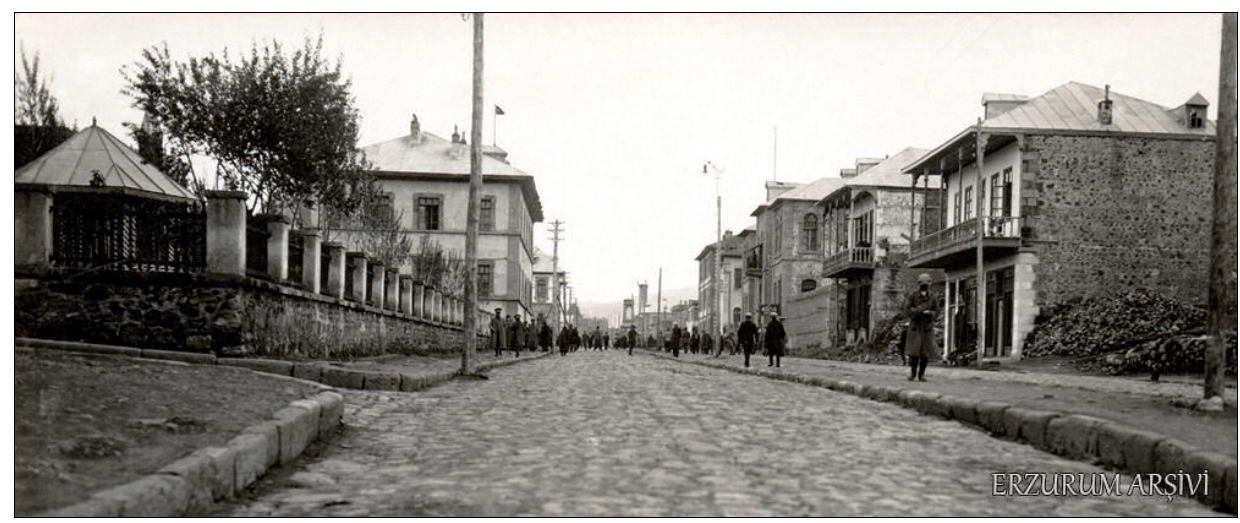

Fotoğraf 10. Erzurum Cumhuriyet Caddesi, Havuzbaşı istikametinden doğuya doğru görünüşü (Erzincankapı Caddesi’nin kuzeye alınması ve caddenin Tebrizkapı ile aynı düzleme çekilmesi sonrasının görünüşü).

Cumhuriyet Caddesi'nin en önemli belirleyicilerinden birisi de 1932-34 yılında batı istikametinde aynı düzlem üzerine uzatılma imarıdır. Mumcu-Erzincankapı kavşağından Havuzbaşı'na kadar olan alan açılmış ve Çaykara Dersi üzerine de buradaki Kültür Kurumu İlkokulu bahçe duvarı hizasına bir köprü yapılmıştır. Cumhuriyet Caddesi batıya doğru uzatılarak günümüzdeki biçimini alması doğrusal hat ve geometrik oluşum bakımından çok önemlidir. Ancak yılların birikimi ile meydana çıkmış olan ritmik yapı düzeni kaybolmuştur. Erzincankapı-Mumcu kavşağından itibaren; Cennetzadelerin Vakıfları (kütüphane, medrese, konak ve köşk), Müşir Konağı, Gemalmazların Konağ 1 ve müştemilat1, Ebulhindili Aslan Bey'in Konağı, Emval-i Milliye mülkleri, Şerafeddin Usta mülkleri, Karakullukçuların hamam ve zaviyeleri, Yukarı Mazî Değirmeni ve Kültür Kurumu İlkokulu gibi birçok yapı yıkılmıştır. Nihayetinde 1934 yılı itibariyle Cumhuriyet Caddesi günümüzdeki biçimini almışıır. Günümüzde Havuzbaşı alanındaki "Cumhuriyet Meydanı" da bu imar faaliyeti sırasında oluşmuştur.

Cadde üzerinde 1920 yılında yapılan ağaçlandırma, 1936 yılında da yapılmış ve orta banket düzenlenerek peyzaj düzenlemesi planlı bir şekilde tamamlanmıştır. 1937 yılında Gürcükapısı'ndan Lalapaşa Cami önüne kadar olan yol cadde haline getirilmiş ve kaldırımı yapılmışıtır. Cumhuriyet Caddesi'nde yol tesviye edilmiş ve kaldırımlar ile caddenin tamamı ilk kez parke taş döşenmiştir.

1938 yılında bölge genel müfettişi Tahsin Uzer'in girişimleri ile Fransız Uzman Jacques H. Lambert'in hazırladığı imar planı Cumhuriyet Caddesi'nin merkezini bir kez daha değiştirmiştir. Havuzbaşı kent meydanı merkezine bağlı olarak yapılan yeni imar faaliyetleri, caddenin batıya taşmasına sebep olmuştur. Mumcu kavşağından 
batıya doğru imar edilen ve "Grup İnşaat"45 adı verilen yapılar, "Cumhuriyet Caddesi'ni yeniden biçimlendirmiş̧ir. Cadde üzerindeki; "Vakıf Apartmanları", modern bir otel olarak yapılan ancak Orduevi/Polisevi olarak kullanılan bina, eski postahane, inhisar(tekel)/KUDAKA binası, Halk Eğitim Merkezi, Şehir Kütüphanesi/Kolordu Binası, bu dönemde inşa edilen büyük yapılardandır (Kurt, 2016: 208).

Cumhuriyet Caddesi, II. Dünya Savaşı sırasında ortaya çıkan ekonomik kriz nedeniyle çok bakımsız kalmıştır. 1946 yılında caddede boş olan çoğu yere barakalar yapılmıștır. Bu barakaların çok çirkin bir görüntü oluşturduğu ile ilgili belediye meclis zabıtlarında oldukça fazla ihtiraz görüşleri yer almaktadır. ${ }^{46}$

\section{Ç. Cumhuriyet Caddesinin Bakım ve Temizliği}

Osmanlı öncesinde caddenin bakımı ile ilgili yeterince bilgi olmasa da Türk hâkimiyeti döneminde ticari faaliyetlerin yoğunluğu nedeniyle "Ahi Teşkilatı"nın bu görevi yaptığı anlaşılmaktadır. Osmanlı döneminde 1591 ve 1642 tarihli arşiv kayıtlarına göre: İçkale burçları, hisarları, hisar yolu, beylik ambarları ve damların bakımları, onarımları ve temizlikleri, Müdürge, Gez ve Ortuzu gibi ova köylüleri tarafindan yapılmaktadır ${ }^{47}$. Osmanlı idaresinde uzun yıllar boyunca caddenin bakımı ve temizliğinin ova köylüleri tarafından bazı vergilerin muafiyeti karşıllğında yapıldığı anlaşılmaktadır. XIX. yüzyıla kadar bu uygulamanın devam ettiğini ve bu tarihten 1920'li yılların ortalarına kadar şehrin temizliği, Vilayet Teşkilatı ve belediye tarafından şahıslara ihale edilerek idame ettirilmiştir. $\mathrm{Bu}$ tarihten sonra temizlik hizmetleri, belediye tarafindan hayvan ve araba temin edilerek emanet usulü yaptırılmaya başlanmıştır. 1930 yılından sonra tanzifat amelesi adı ile temizlik işçisi kadrosu tahsis edilmiş ve araçlar değişse de bu sistem günümüze kadar gelmiştir.

\footnotetext{
${ }^{45}$ Yukarıdaki yapıların dışında: Kolordu Destek Komutanlığı, Maliye ve Defterdar Lojmanları, Rektörlük Lojmanı; Paşalar Caddesi'nde: Vali Konağı, 3. Ordu Paşa Karargâhı, Arkeoloji Müzesi binaları da bu dönemde Grup İnşaat tarafindan yaptırılmıştır.

${ }^{46}$ Erzurum Belediyesi Arşivi, Meclis Zabıtları, 28 Haziran 1948.

${ }^{47}$ Bkz. BOA. C.ML, 666/27292, 23 L. 1201; Abdurrahim Şerif Beygu (1936). Erzurum, Tarihi, Anıtları, Kitabeleri, İstanbul: Bozkurt Basımevi, s. 25; Murat Küçükuğurlu-Şemseddin Çelik (2013). Erzurum Kalesi, İstanbul: Mas Matbaacılık, s. 111.
} 


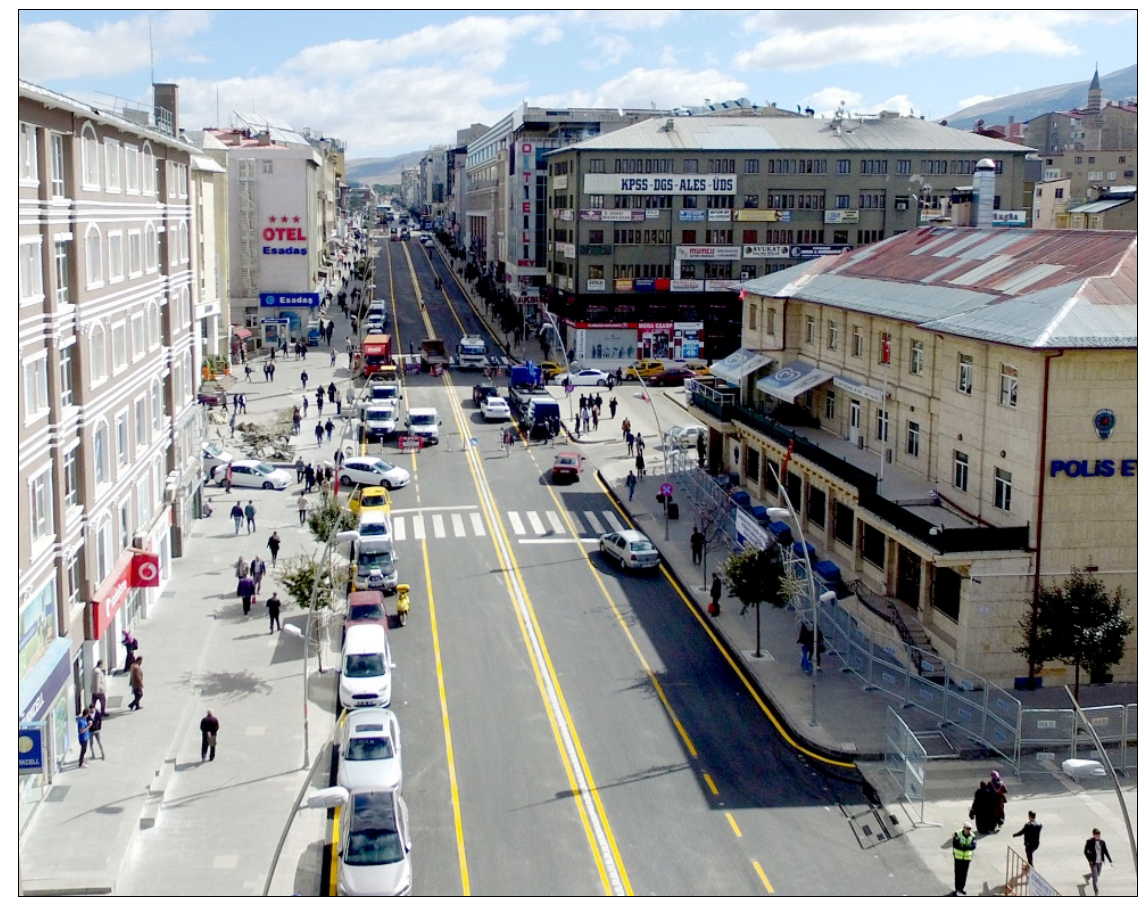

Fotoğraf 11. Cumhuriyet Caddesi'nin günümüzdeki görünüşü.

Osmanlı döneminde belli noktalara konulan meşale ve sonrasında da kandil fanusları ve fitilli gazlı lambalarla aydınlatılan cadde, 1925 yılında resmi dairelerin bulunduğu kısımlarda elektrikli sokak lambaları ile ışıklandırılmıştır. 1930'lu yıllarda geliştirilen elektrik ağı ile 1940'lı yıllarda caddenin aydınlatılması çoğunlukla sağlanabilmişse de halkın yalnızca yüzde onu elektrik kullanabilmektedir (Küçükuğurlu, 2011: 323).

Organik bir düzenleme ile oluşan Cumhuriyet Caddesi, 1930'lu yıllardan sonra geometrik düzenleme biçimine dönüşmüş ve 1950'li y1llardan sonra da geleneksel dokusunu çok büyük oranda kaybetmiştir.

\section{SONUÇ}

Erzurum şehri, bugünkü yerine 415 yılında Bizans İmparatoru II. Theodosius döneminde (408-450) kale şehir olarak kurulmuştur. Roma şehirlerinde olduğu gibi yuvarlağa yakın bir sur çevirmesi içerisine alınan şehrin bu dönemde mimari yapılanması da daire geometrisine uygun olarak gelişmiştir. Sur duvarlarını, dört yönde dış dünyaya bağlayan sur kapıları ulaşım ağının da temel belirleyicisi olmuştur. Cumhuriyet Caddesi'nin ilk oluşumu; doğu yönüne açılan "Agusteum/Tebrizkapı" sur kapısı ile batı yöne açılan "Anastasius/Erzincankapı(?)" sur kapısı arasındaki kale yolu 
biçimindedir. Bu dönemde caddeyi iki yakasından sınırlandıracak mimari yapılaşmanın olmayışı, caddenin bir meydan olarak kullanılmasını doğurmuştur.

Kesintiler olsa da, yaklaşık olarak üç yüz yıl boyunca İslam devletlerinin hâkimiyetinde kalan şehrin ana caddesine yeteri kadar müdahale edilmediği anlaşılmaktadır. Bu dönemde şehrin yapısal değişikliğinin hisar kısmında değil, varoş bölümlerde olduğu miladi 651 yılına tarihlenen "Kâbe Mescidi”nin yapıldığı (Yakutiye Belediyesi güneybatısı) yerden anlaşılmaktadır. Müslümanların "Tarık-1 Kala" dedikleri cadde asıl imarını, 1080 yılından sonra Saltukoğulları döneminde (10801202) görmüștür. Müslüman Türklerin "Rah-1 Hisar" dedikleri cadde, bu dönemde her iki yakasına yapılan ve günümüze kadar ulaşan abide yapılara kavuşmuş ve Camii Kebir merkezli kent meydanı haline gelmiştir. Kale Mescidi ve Tepsi Minare (1124); hâkimiyet, Atabek/Ulu Camii (1179); otorite, Üç Kümbetler (1189); ebedi yurt imgeleri ile Müslüman Türk milletinin sembolleri olarak bu dönemde caddeyi ve şehri şekillendirmiştir. Selçukluların zamanında (1202-1242) şehir, çok zengin ve gelişmiş ticaret merkezi, cadde de iç meydan biçiminde canlı bir alanına dönüşmüştür.

Cumhuriyet Caddesi, günümüze en yakın biçimini İlhanlıların hâkimiyetinde (1256-1335) almıştır. İlhanlılar zamanında caddenin her iki yakasının sınırlarını belirleyecek olan: Çifte Minareli Medrese (XIII. yüzyılın son çeyreği), Cimcime/Çengâl Hatun Kümbeti (1304) Yakutiye Medresesi (1310), günümüzde Menderes Caddesi, dört yol kavşağındaki Sultaniye Medresesi (XIV. yy başları), Ahmediye Medresesi (1314) gibi büyük anıtsal yapılar inşa edilmiştir. Bu dönemde caddenin Cumhuriyet dönemine kadar kullanılacak olan biçimi belirlenmiştir. Tebrizkapı'dan Erzincankapı'ya ulaşan cadde günümüz güzergâhından güneye doğru kıvrılarak "Erzincankapı Çarşısı"nı takip etmekte ve Kırkdeğirmenler Deresi üzerine Timurlular zamanında yapılan Fil Köprüsü ile batı yöne bağlanmaktadır.

Osmanlı döneminde (1518-1923), Lalapaşa Camii güneyine yapılan "Beylerbeyi Sarayı" ile caddenin merkezi buraya taşınmıștı. Eyalet yönetim birimi olan Beylerbeyi Sarayı'nın etrafina yapılan askeri, dini, ilmi, kamu ve ticari yapılar, caddeyi yeniden yapılandırmıştır. Cadde, ilk kez Ayas Paşa döneminde (1558-1560) genişletilerek resmi olarak belli bir düzende büyütülmüştür. Bu dönemde caddeye, "Ayas Paşa Yolu", "Sarayönü" ve "İç Meydan" gibi adlar verilmiştir. Cadde, yapılan genişleme ve mimari yapılaşma ile geleneksel dokulu bir Osmanlı caddesi görünümü kazanmışıtır. Caddeyi oluşturan organik gelişme dokusu, kentin bütün biçimsel karakterine de yansımıştır. Erzurum şehrinin tipik mimari yapısının gelişme gösterdiği ana cadde ve etrafındaki sokakların düzeni ve bu sokak düzeni içerisinde mimari eserlerin ve konutların konumlanışları tipik Osmanlı kentlerindeki gibi olmuştur. Özellikle Sarayönü/Iç Meydan olmak üzere cadde, ticari faaliyetlerin yoğunlukta olduğu, bireylerin yoğun kullanımına sahne olan ve insan hareketlerinin yönlendiği mekân olarak günümüzdeki işlevine yakın bir konumdadır.

Cumhuriyetin ilk yıllarında, I. Ulusal Mimari Üslubu ile yapılan, Hükumet Konağı, Mevkii Müstahkem Binası, Cumhuriyet Oteli, Erzurum Kimyahanesi, Şehir Kütüphanesi, Cumhuriyet Sineması gibi yapılar Osmanlı döneminde belirlenen merkez 
noktasındadır. Bu dönemde caddenin en önemli imarı, 1934 yılında ErzincankapıMumcu kavşağından Havuzbaşı'nın bulunduğu Cumhuriyet Meydanı'na kadar caddenin aynı düzlemde uzatılmasıdır. Yine bu dönemde, ilk düzenli imar planı ile şehrin merkezi çekim alanı bir kez daha batıya; günümüzdeki Havuzbaşı Meydanı'na aktarılmıştır. 1938 yılında Lambert tarafından yapılan imar planı, bir yandan caddenin batı uca yönelimini gösterirken bir yandan da organik sistemin geometrik düzene evrildiğini göstermektedir.

Çok kültürlü bir yapı katmanı oluşturan Erzurum Cumhuriyet Caddesi, şehrin kendiliğinden gelişen doğal imarının en önemli belirleyicisidir.

\section{Kaynaklar}

Arslan, M. (2020, 05 Eylül). Saltuklu kent meydan1. (ET:20.01.2021). www.25haber.com.

Aydın, B. (2014). Osmanlı dönemi Erzurum Murat Paşa Cami. Akademik Sosyal Araştırmalar Dergisi, 7, 152-160. https://doi.org/10.16992/ASOS.362

Aydın, D. (1998). Erzurum Beylerbeyliği ve Teşkilatı Kuruluş ve Genişleme Devri (1535-1566). TTK Basımevi.

Aydınlı, A. (2007). Sahabe coğrafyasının bir parçası olarak Doğu Anadolu, Türk İslam Düşünce Tarihinde Erzurum Sempozyumu I-II.

Başar, Z. (1977). Tarih Boyunca Çeşitli Hizmetleriyle Camilerimiz/Erzurum Camileri. Atatürk Üniversitesi Yayını.

Beygu, A. Ş. (1936). Erzurum Tarihi Anıtları Kitabeleri. Bozkurt Basımevi.

Bozkurt, N. (2000). İpek Yolu. TDV İslam Ansiklopedisi XXII, 369-372.

Can, B. (2010). Hellenistik, Roma ve Bizans dönemlerinde Erzurum çevresi. Geçmişten Geleceğe Armağan Dergisi, 34-39.

Günaşdı, Y. (2015). Erzurum Kalesi'nde tespit edilen usta monogamları. Belgü Ardahan Üniversitesi İnsani Bilimler ve Edebiyat Fakültesi Dergisi. Y1l 1, (2), 223-252.

Gürbüz, O. (2004). Anadolu Selçukluları Döneminde Erzurum. Bakanlar Medya.

Gürbüz, O. (2016). Kalîkalâ-Erzen isimlerinin menşei ve Erzurum'un fethine dair bazı değerlendirmeler. İahiyat Tedkikleri Dergisi. 2016/2, (46), 131-143.

İbn Bîbî, Hüseyin b. Muhammed b. Ali (684/1285). (1996). el-Emâviru'l Alâiyye fi'lUmûri'l-Alâiyye (Selçuknâme) (M. Öztürk, Cev. ) Kültür Bakanlığı Yayını. 
İbnü'l-Esîr, Ebü'l-Hasan İzzeddin Ali b. Muhammed b. Abdülkerim. (1985). İslâm Tarihi: el-Kâmil fi't-Tarih Tercümesi (1-12). (A. Ağırakça vd., Cev.) Bahar Yayınları.

Karabekir, K. (1993). İstiklâl Harbimiz I. Truva Yayınları.

Karamağaralı, H. (1971). Erzurum'daki Hatuniye Medresesi'nin tarihi ve banisi hakkında mülahazalar. Selçuklu Araştırmaları Dergisi III Malazgirt Zaferi (Özel Saylsl), 209-259.

Kılıç, Ü. (2009). Erzurum'da Cafer Efendi Vakfi. Atatürk Üniversitesi Türkiyat Araştırmaları Enstitüsü Dergisi, 41, 173-187.

Konukçu, E. (1989). Tarih'de Erzurum. Şehr-i Mübarek Erzurum. Yorum Matbaacılık.

Konukçu, E. (1992). Selçuklulardan Cumhuriyete Erzurum. ETO Yayını.

Konyalı, İ. H. (1960). Abideleri ve Kitabeleri ile Erzurum Tarihi. Ercan Matbaası.

Kulözü, N. (2016). Bir mekânsal modernleşme öyküsü: Erzurum kenti ve kentsel mekânında ikili dokunun oluşumu. İdealkent Dergisi. 7 (18), 22-47.

Kurt, A. (2016). Havuzbaşından Cumhuriyet Caddesi'ne giriş. Y. Kotan ve M. H. İspirli (Eds). Hatıralardaki Erzurum (I. bastm, ss. 205-213). Zafer Medya.

Küçükuğurlu, M. (2008). Erzurum Belediyesi Tarihi I, Dergâh Yayınları.

Küçükuğurlu, M. (2013a). Erzurum Tabyaları ve Kışlaları. Mas Matbaacılık.

Küçükuğurlu M., (2018). Erzurum Çarşı Pazar, Eski Erzurum Çarşıları ve Üretim Mekânları, Çizgi Kitabevi.

Küçükuğurlu, M. (2018a). Sorularla Erzurum Tarihi. Çizgi Kitabevi.

Küçükuğurlu, M. (2020). Erzurum Camileri Medreseleri Kütüphaneleri. Çizgi Kitabevi.

Küçükuğurlu, M. ve Çelik, Ş. (2013). Erzurum Kalesi. Mas Matbaacılık.

Kürkçüoğlu, E. (2007). Ortaçağ’ da Erzurum V-XV. Yüzyıllar. Güneş Vakfı Yayınları.

Moses Khorenats'i. (2006/ Orijinali 8. yüzyılda yazılmıştır). History of the Armenians. (R. W. Thomson, Çev.) Caravan Books.

Özkan, H. (2002), Saltuklu mimarisi. Türkler, C.8, 72-82.

Özkan, H. (2015). Erzurum Caferiye Külliyesi ve restorasyonları. Atatürk Üniversitesi Güzel Sanatlar Enstitüsü Dergisi Journal of the Fine Arts Institute (GSED), 34, 4681.

Özkan, H. (2016). Saltuklu Mimarisi. Zafer Medya Grup. 
Pamuk, B. (2007). İpekyolu ticareti ve Erzurum. Tarih Incelemeleri Dergisi, 22 (2), 125-143.

Polat, M. (1957, 19 Haziran). Yakutiye Camii'nin düşündürdükleri. Hür Söz Gazetesi.

Sağlam, T. (2019). Geleneksel Erzurum Evleri, Restorasyonları ve Ev Yaşantısı. (Yayımlanmamış Doktora Tezi). Atatürk Üniversitesi, Sosyal Bilimler Enstitüsü.

Sağlam, T. ve Yurttaş, H. (2020). Geleneksel Erzurum evlerinin istatistiki veri analizi. Türkiyat Araştırmaları Enstitüsü Dergisi - Journal of Turkish Researches Institute 67, 421-458.

Sağlam, T. (2020). İslam mimarisinin sembolik anlatıları üzerine bir deneme International Journal of Interdisciplinary and Intercultural Art, 5 (10), 251-279.

Taşyürek, M. (2010). Erzurum Türbeleri ve Ziyaret Yerleri, Palandöken Belediyesi Kültür Serisi 3.

Taşyürek, M. (2016). Osamnlı'dan Cumhuriyet'e uzanan bir mahalle: Muratpaşa. Y. Kotan ve M. H. İspirli (Eds). Hatıralardaki Erzurum (I. basım, ss. 189-204). Zafer Medya.

Tozlu, S. (2011, 11 Haziran). Erzurum sazlıklarını arıyor. Erzurum Gazetesi.

Ünal, R. H. (1974). Erzurum ili dâhilindeki İslami devir anıtları üzerine bir inceleme. Atatürk Üniversitesi Edebiyat Fakültesi Araştırma Dergisi, Nisan 1973 (6), 49142.

Yurttaş, H. ve Kındığılı M. (2011). Kesinleşen tarih ve yeni bir ad. Atatürk Üniversitesi Edebiyat Fakültesi Sosyal Bilimler Dergisi Journal of Social Sciences, Cilt 11 (46), 75-96.

Yurttaş, H. ve Köşklü, Z. (2017). Erzurum ili vakfiyelerinde taş özetler, Türk Dünyası Dil ve Edebiyat Dergisi, 44, 355-379. http://Dx.Doi.Org/10.24155/Turkishstudies.2017.47

Yurttaş, H. (1998). Erzurum Surları, Sanatsal Mozaik Dergisi, 29, 93-107.

Yurttaş, H. (2001). Erzurum Ulu Camisi'ne ait yeni bir kitabe ve yapı hakkında bazı düşünceler. Atatürk Üniversitesi Türkiyat Araştırmalarl Enstitüsü Dergisi, 17, 191-207.

Yurttaş, H. ve Özkan, H. (2002). Tarihi Erzurum Çeşmeleri ve Su Yolları. Erzurum Büyükşehir Belediyesi Yayını.

Yuvalı, A. (2000). İlhanlılar. Türkiye Diyanet Vakfi Ansiklopadisi XXII, 102-105.

Zeynal, A. (2016). Havuzbaşı'ndan Karskapı'ya yürürken. Y. Kotan ve M. H. İspirli (Eds). Hatıralardaki Erzurum (I. basım, ss. 215-225). Zafer Medya. 